\title{
Assessing the Effects of the Green-Blue Municipality Program on Human Health in the State of São Paulo, Brazil
}

\author{
Henrique dos Santos Maxir ${ }^{1}$ (D) | Maria Cristina Galvão ${ }^{2}$ (D) | Rayssa Alexandre Costa $^{3}$ (D) | \\ Iara Maria da Silveira ${ }^{4}$ iD | Alexandre Nunes Almeida ${ }^{5}$ \\ ${ }^{1}$ Escola Superior de Agricultura Luiz de Queiroz, Universidade de São Paulo. E-mail: \\ henriquemaxir@alumni.usp.br \\ ${ }^{2}$ Escola Superior de Agricultura Luiz de Queiroz, Universidade de São Paulo. E-mail: \\ galvao.mariacristina@gmail.com \\ ${ }^{3}$ Escola Superior de Agricultura Luiz de Queiroz, Universidade de São Paulo. E-mail: rayssa.costa@usp.br \\ ${ }^{4}$ Escola Superior de Agricultura Luiz de Queiroz, Universidade de São Paulo. E-mail: iaramaira.silveira@gmail.com \\ ${ }^{5}$ Escola Superior de Agricultura Luiz de Queiroz, Universidade de São Paulo. E-mail: alex.almeida@usp.br
}

\begin{abstract}
The Green-Blue Municipality Program (GBMP) was implemented in 2008 by the government of São Paulo State, Brazil. This program has as main goal to improve the environmental quality through actions based on ecofriendly directives. This study evaluates the impact of GBMP certification on hospitalizations regarding air quality and cases of diseases due to contact with contaminated water in São Paulo State from 2007 to 2015. This analysis focuses on the effects of post-certification, then pre-certification effects are not identified, classifying this analysis as partial. The identification strategies used were Propensity Score Matching and Difference-inDifferences. Estimates suggest that no significant reduction in the cases of diseases related to polluted water and air quality is observed in municipalities that received the GBMP certificate in initial years.
\end{abstract}

\section{KEYWORDS}

Waterborne and airborne diseases, Impact evaluation, Public policy

Avaliando os Efeitos do Programa Municipio Verde-Azul na Saúde Humana no Estado de São Paulo, Brasil

\section{RESUMO}

O Programa Município Verde Azul (PMVA) foi implementado em 2008 pelo governo do Estado de São Paulo, Brasil. Este programa tem como principal objetivo melhorar a qualidade ambiental por meio de ações baseadas em diretivas benéficas para o meio ambiente. Este estudo avalia os impactos da certificação do Programa Município Verde Azul sobre o número de hospitalizações relacionadas a qualidade do ar e os casos de doenças devido ao contato com água contaminada no estado de São Paulo no período de 2007 a 2015. Ao olhar para o impacto da pós-certificação, os efeitos pré-certificação não são identificados, o que classifica essa análise como parcial. A estratégia de identificação utilizada foi o modelo de Pareamento por Escores de Propensão combinado com Diferenças-em-Diferenças. As estimativas indicam que nenhuma redução significativa no número de casos de doenças foi observada nos municípios que receberam a certificação do PMVA nos anos iniciais.

\section{PALAVRAS-CHAVE}

Doenças transmitidas pela água e pelo ar, Avaliação de impacto, Política pública 


\section{Introduction}

The socio-environmental issue is often left out of the agenda of municipal policies with the development of urban areas, ignoring ecological problems. Environmental public policies need to be implemented to develop better models of conservation planning and management. Moreover, they are necessary to fight current challenges in urban regions and end the idea that economic and political values overcome the environmental ones (Moreira Jr, 2010; Oliveira et al., 2013). An environmental public policy is well defined when objectives of the program are linked to environmental protection, sustainability, environmental resource management and prioritization of ecological quality (Barbosa, 2014).

The state of São Paulo is the most urbanized and populated in Brazil with $645 \mathrm{mu}$ nicipalities, an estimated population of 44,749,699 and a monthly nominal household income per capita of $\mathrm{R} \$ 1,723^{1}$ in 2016 (IBGE, 2017) ${ }^{2}$. The state covers industrialized urban regions in areas such as the capital of state, the metropolitan region of São Paulo and cities in the countryside such as Campinas, Ribeirão Preto and Sorocaba. To keep the industry active in the state a substantial amount of materials, energy, and water are required. However, the use of the materials is not usually driven in a sustainable way, which generates waste that is not properly discarded, polluting the air and water. Notwithstanding, the air pollution generated by cars and trucks has also negative effects on human health especially in densely populated regions (Zhao et al., 2016). All these processes are like a centrifugal force that leads to economic and spatial dissipation due to the negative externalities that they generate (Moraes and Serra, 2006). To mention some of them, air and water contamination can cause highly damaging effects to the population health in the polluted areas (Giatti et al., 2004). Studies have shown a strong correlation between air pollution and respiratory diseases (Braga et al., 2001; Mazzoli-Rocha et al., 2008; Nardocci et al., 2013; Chagas et al., 2016; Freitas et al., 2016).

According to Braga et al. (2001), although combustion engines, steel and chemical industries were economic activities that emerged in the last century, their impacts on the environment and human health have not yet been considered accordingly. Air pollution has been a problem since the mid-20th century, particularly in industrialized urban centers and with the presence of automobiles, such as the Metropolitan Region of São Paulo (MRSP). Nardocci et al. (2013) evidenced this relation in the city of Cubatão, an industrial pole of petrochemicals, steel, and fertilizers of São Paulo State. Pollutants had a significant impact on the number of hospitalizations due to the respiratory diseases, mainly, on children under 5 years of age.

According to Freitas et al. (2016), the burning of fossil fuels, for example, generates pollutants such as coarse Particulate Matter $\left(\mathrm{PM}_{10}\right)$, sulfur trioxide $\left(\mathrm{SO}_{3}\right)$, carbon monoxide $(\mathrm{CO})$, nitrogen oxides $\left(N O_{x}\right)$ and ozone $\left(\mathrm{O}_{3}\right)$. Moreover, the burning of fossil

\footnotetext{
${ }^{1}$ In real values of 2016 and US\$ 528.67.

${ }^{2}$ Information from IBGE States, available at: http://www.ibge.gov.br/estadosat/.
} 
fuels, such as gasoline and diesel, is more toxic than the burning of biomass fuels, such as ethanol (Braga et al., 2001). However, according to Mazzoli-Rocha et al. (2008), biomass burning is the main responsible for the accumulation of Total Suspended Particles (TSP) worldwide, causing high pollution levels, mainly in developing countries. São Paulo State is Brazil's largest producer of sugarcane ${ }^{3}$. Until 2013, the practice of burning sugarcane straw in the field ${ }^{4}$ was common, which also contributed to increased air pollution ${ }^{5}$. Similarly, Chagas et al. (2016) studied the impacts of sugarcane production on health conditions of individuals in the cultivated areas and in their vicinity using data from municipalities of São Paulo State. The authors found that sugarcane burning increased the number of hospitalizations due to respiratory diseases, because mostly to a large amount of toxic particles and gases released.

Therefore, mortality and morbidity rates related to respiratory and cardiovascular problems are important indicators of air pollution effects on human health. The increase in asthma attacks and pre-cordial pain, functional limitation, use of medications, number of visits to emergency room and hospital admissions indicate the main problems observed related to urban air pollution (Braga et al., 2001). In addition, a few number of Brazilian studies analyzed infections by diseases related to direct or indirect ingestion of contaminated water (Christovão et al., 1967; Amaral et al., 2003; Silva and Araújo, 2003; Giatti et al., 2004; Silva, 2012; Lima and Freitas, 2014).

Christovão et al. (1967) emphasized how contaminated water for irrigation in vegetable gardens and indirect management can serve as an infection vehicle for consumers, especially in the case of lettuce. Amaral et al. (2003) point out that human consumption is one of the most important vehicles of water diseases, such as diarrhea. Silva and Araújo (2003) highlight that ingestion of contaminated water has been associated with different health problems such as gastrointestinal epidemics, reducing resistance of individuals, such as children and the elderly. Giatti et al. (2004) reported the conditions of basic sanitation in the city of Iporanga in São Paulo State, highlighting that pollution of rivers and streams by domestic sewage, along lack of sanitary knowledge by the population, increases contamination risks by intestinal parasitic diseases, such as schistosomiasis.

Due to impacts of pollution on health and well-being of individuals, public policies have the responsibility to mitigate negative externalities and control new emissions. Public policies - when enforced properly - can influence production systems, how people live, and are not only instruments for social development, but also as specific way of preservation of natural resources, ensuring life quality (Salheb et al., 2009).

\footnotetext{
${ }^{3}$ According to UNICA (2017), in the harvest of 2012/2013 the São Paulo State produced 330 million tons of sugarcane, representing $56 \%$ of Brazilian production.

${ }^{4}$ According to Mazzoli-Rocha et al. (2008), in the Araraquara city, located in the State of São Paulo, the burning of sugarcane straw was associated with an increase in the number of patients in hospitals that needed inhalation therapy, as well as an increase in hospitalizations of children and elderly with respiratory diseases. Therefore, the quality of the air was deteriorated in the period of the called "burnings", mainly in the cities of São Paulo State with sugarcane production.

${ }^{5}$ The study conducted by Mazzoli-Rocha et al. (2008) showed that particles derived from the burning of sugarcane biomass are as toxic as those produced by normal vehicular traffic.
} 
Therefore, the objective of this study is to analyze the impacts of a regional public policy, the Green-Blue Municipality Program (GBMP) ${ }^{6}$, on municipalities of São Paulo State, in Brazil from 2007 to 2015. Specifically, we evaluate the impact of receiving the GBMP certification on the number of diseases related to ingestion of contaminated water and associated with air pollution, such as respiratory diseases ${ }^{7}$.

The municipalities participating in the GBMP, through the certification of GreenBlue Municipality ${ }^{8}$, receive economic benefits that are converted into incentives for executive, legislative, and civil society for implementation of proposed directives by the program. The compliance with the directives allows improvements in water management, sewage collection and air quality. Then, our hypothesis is that the greater number of municipalities joining the GBMP, smaller the number of hospitalizations and confirmed cases of respiratory diseases and illnesses related to ingestion or contact with contaminated water decreases, reducing negative externalities related to water and air pollution.

Although the main objective of this study is to assess the impacts of receiving GBPM certification on the number of cases of diseases related to air and water quality in the municipalities of the São Paulo State, there is a possibility of a pre-certification effect. The granting of such benefit is only made to those municipalities that obtain a certain score from the Environmental Assessment Index (EAI), that is, municipalities are required to improve the environmental quality even before receiving the certification. Thus, our study is limited and offers only a partial analysis of the effects of the program. The paper is divided into five sections, including this introduction. Section 2 presents a brief description of the GBMP, while section 3 shows the methodology applied in this study and a summary of the database and their sources. Section 4 presents the estimated results and the tests; and, finally, section 5 suggests policy considerations about the results and the program analyzed.

\section{Green-Blue Municipality Program (GBMP)}

The Green-Blue Municipality Program (GBMP) was stablished in 2007 by the Secretariat of Environment of the São Paulo State (SMA) ${ }^{9}$, and its main objective is to compose an agenda of shared environmental management actions and mutual accountability of municipalities in order to have control of environmental quality. There is also an improvement of sustainable development and an active participation of municipal population to implement the program. Specifically, the GBMP seeks to encourage a more effective participation of municipalities establishing a plan of 10 goals that allows an adequate integration between the municipal environmental agenda and the state agenda. These goals considered main priorities by the SMA (2016) are presented in Table 1.

\footnotetext{
${ }^{6}$ In Portuguese, the public policy is called "Programa Municipio Verde-Azul (PMVA)".

${ }^{7}$ Section 3 presents the description of the diseases considered in the analysis.

${ }^{8}$ In Portuguese, "Certificado de Município Verde-Azul".

${ }^{9}$ In Portuguese, "Secretaria do Meio Ambiente do Estado de São Paulo (SMA)".
} 
Table 1. Directives of Green-Blue Municipality Program

\begin{tabular}{|c|c|}
\hline Directives & Fundamental Objectives \\
\hline 1. Sewage Treatment & $\begin{array}{l}\text { To increase the rates of collection, transportation, treatment, and } \\
\text { appropriate disposal of urban sewage. }\end{array}$ \\
\hline 2. Water Management & $\begin{array}{l}\text { To strengthen the municipal management on water quality, } \\
\text { mainly in the public supply of water. }\end{array}$ \\
\hline 3. Solid Waste & $\begin{array}{l}\text { To fortify the management of solid household waste and civil } \\
\text { construction rubble; and to stimulate the programs/actions of } \\
\text { selective collection and post-consumer responsibility. }\end{array}$ \\
\hline 4. Sustainable City & $\begin{array}{l}\text { To increase the awareness and commitment to sustainable } \\
\text { development practices as a way of vulnerabilities reduction, providing } \\
\text { resilience and fostering well-being and security to citizens. }\end{array}$ \\
\hline 5. Biodiversity & $\begin{array}{l}\text { To protect and/or recover/restore strategic areas for the } \\
\text { maintenance of natural resources. }\end{array}$ \\
\hline 6. Urban Afforestation & $\begin{array}{l}\text { To increase the management of the urban environment } \\
\text { through the planning and the definition of priorities for } \\
\text { urban afforestation. }\end{array}$ \\
\hline 7. Environmental Education & $\begin{array}{l}\text { To implement environmental education at formal and informal } \\
\text { level in three areas: training, professional qualification, } \\
\text { and community mobilization. }\end{array}$ \\
\hline 8. Air Quality & $\begin{array}{l}\text { To implement activities and to participate in initiatives that } \\
\text { contribute to the maintenance or improvement of air quality and } \\
\text { control the excess of greenhouse gases emissions. }\end{array}$ \\
\hline 9. Environmental Structure & $\begin{array}{l}\text { To stimulate the strengthening of the } \\
\text { Secretariats, Departments, and Directorates of Environment. }\end{array}$ \\
\hline 10. Environmental Council & $\begin{array}{l}\text { To stimulate the regular functioning of the } \\
\text { Environment Municipal Councils. }\end{array}$ \\
\hline
\end{tabular}

Source: SMA (2016).

Based on the analysis and evaluation of municipal performance in relation to the proposed directives, the Environmental Assessment Index (EAI) ${ }^{10}$ is constructed for each municipality that adheres to the GBMP. The EAI is calculated as follows:

$$
E A I=\sum w_{i} P_{i}-P L
$$

where $w_{i}$ is the weight that each Environmental Directive has on $\mathrm{EAI}^{11}$ and $P I_{i}$ is the Performance Indicator for each Environmental Directive $(i)$ in the GBMP. This indicator

${ }^{10}$ For more information about the GBMP and the construction
EAI see the GBMP Manual 2016 ("Manual do PMVA"), available in:
<http://arquivos.ambiente.sp.gov.br/municipioverdeazul/2011/11/PMVA-MANUAL.pdf>. The
dicator construction criteria have changed over time, becoming stricter. Therefore, it could result in an
underestimation of the real effects of the program on disease variables. The year-to-year criteria can be
found at: www.infraestruturameioambiente.sp.gov.br/verdeazuldigital/criterios/
${ }^{11}$ Table A.1 in Appendix A contains the weights of each directive.


varies on a scale from 0 (zero) to 10 (ten) and the score is attributed according to the actions proposed and it is adjusted by the weight of each directive while $\sum P I_{i}$ refers to the sum of each Performance Indicators, which the maximum value is 100 (one hundred) points and $P L$ consists of any type of pendency and/or environmental liabilities of the municipality. This value ranges from 0 (zero) to 30 (thirty), according to the liabilities established by the Environmental System of the São Paulo State.

According to the results of EAI, the SMA annually publishes the Environmental Ranking of the municipalities of the São Paulo State for the knowledge of municipalities and population in general. Figure 1 shows the evolution of municipalities certified by the program. The certificate "Green-Blue Municipality" is granted only to municipalities that achieve score equal to or greater than 80 points in EAI. The major advantages of this certification are the resources received from the São Paulo State Fund for Pollution Prevention and Control (FECOP) ${ }^{12}$ and the priority in state funds related to environmental investments (Oliveira et al., 2013; Andrade and Talamoni, 2013). The FECOP resources received by the municipalities can be spent mainly on vehicles and equipment to prevent fires, management of solid waste and preserve biodiversity, for instance CETESB (2020).

Figure 1. Evolution of the certified and non-certified municipalities by the Green-Blue Municipality Program from 2008 to 2016

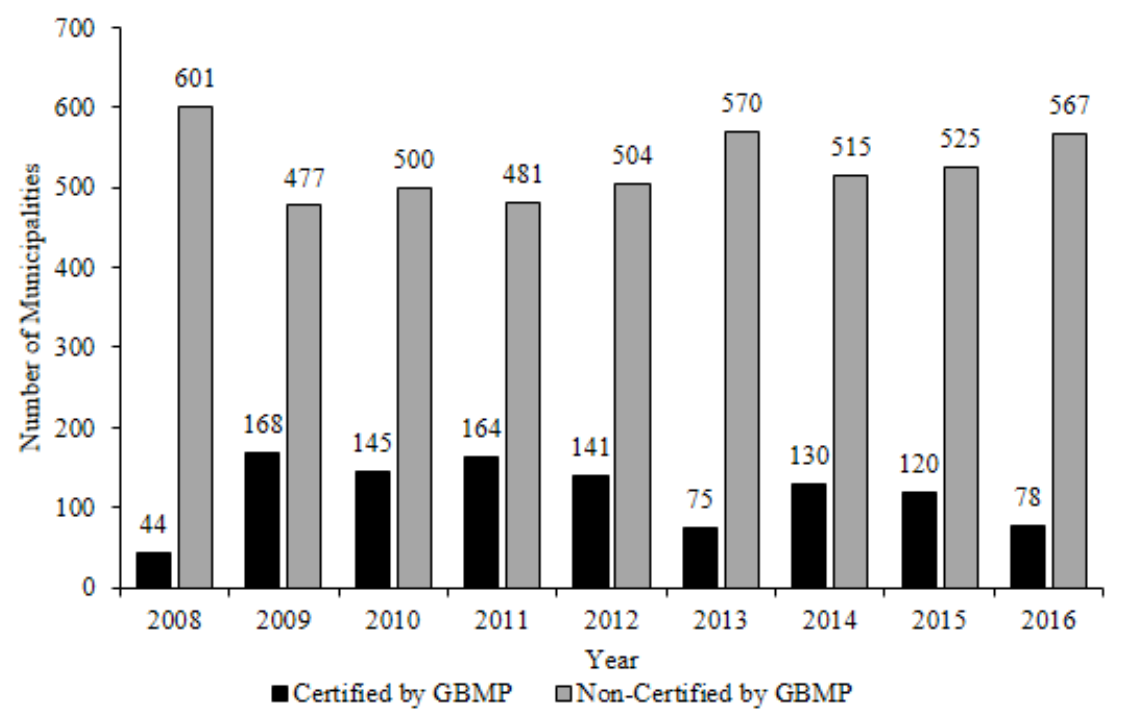

Source: Elaborated by the authors based on SMA (2016).

\footnotetext{
${ }^{12}$ In Portuguese, "Fundo Estadual de Prevenção e Controle da Poluição (FECOP)”. Unfortunately, there are no available information on the percentage of municipalities that received FECOP resources and neither the amount received over the years.
} 


\section{Methodology}

In the public policies evaluation, the ideal estimate of the effect of an intervention (treatment) is to compare a same group of agents participating and non-participating in the program (public policy) (Duflo et al., 2007). However, it is not possible to have the same group, at a given moment of time, in these two contexts simultaneously (Duflo et al., 2007). Thus, the main challenge of evaluating the impacts of a policy is to create a counterfactual scenario (Ravallion, 2007). In addition, a simple comparison between participating and non-participating agents of the program is not adequate, because it can generate selection bias, since entities have distinct observable and non-observable characteristics that may affect their participation in the program evaluated (Duflo et al., 2007; Chabé-Ferret and Subervie, 2013). Therefore, the control group should be statistically identical to the one sponsored by the program, differing only from the fact that it does not receive the benefit (Caliendo and Kopeinig, 2008; Khandker et al., 2009).

\subsection{Propensity Score Matching (PSM)}

The Propensity Score Matching (PSM) method includes the selection of a control group comparable to the treatment group by estimating a probability model (Logit/Probit). The Logit/Probit model evaluates probabilities of participating in the treatment and the matching of groups using observable characteristics. The propensity score approach, developed by Rosenbaum and Rubin (1983), is defined as the conditional probability of receiving a treatment, given a vector of pre-treatment observable characteristics such as:

$$
p(X)=\operatorname{Pr}(T=1 \mid X)=E(T \mid X)
$$

where, $T$ indicates the treatment position ( 1 if it is certified by the GBMP and 0 if it is not certified ${ }^{13}$ ) and $X$ is a vector of observable characteristics. Thus, it is possible to calculate the Average Treatment Effect on the Treated (ATT), which is given by:

$$
A T T=E_{P(X) \mid T=1}\left\{E\left[Y_{1 i} \mid T_{i}=1, p\left(X_{i}\right)\right]-E\left[Y_{0 i} \mid T_{i}=0, p\left(X_{i}\right)\right] \mid T_{i}=1\right\}
$$

To calculate the ATT, two hypotheses must be satisfied. The combination of these hypotheses is known as strong ignorability condition (Rosenbaum and Rubin, 1983):

- Hypothesis 1 - Conditional Independence: $Y_{i}(1), Y_{i}(0) \perp T_{i} \mid X_{i}$, that is, unobserved factors do not affect the participation;

- Hypothesis 2 - Common Support: for some $c>0, c<p(x)<1-c$. Therefore, the

\footnotetext{
${ }^{13}$ In this case, the control group is composed only by municipalities that have not received certification in any year of the period analyzed.
} 
treatment observations have "near-by" comparison observations on the distribution of propensity scores.

Since the main objective of PSM is only the classification of the sample, the binary outcome models that evaluate the probabilities may not be crucial Smith (1997); Caliendo and Kopeinig (2008).

The next step in estimating the propensity score is the matching procedure, which can be performed by different methods. In this study, the following methods ${ }^{14}$ are used: 1) Nearest Neighbor Matching; 2) Nearest Neighbor with caliper; 3) Mahalanobis technique (Covariate Matching); and 4) Non-Parametric Kernel regression. After the matching procedure, balancing tests are performed, ensuring the comparison of comparable groups. Rosenbaum and Rubin (1983) state that the standardized bias cannot exceed $20 \%$ and the p-values should not be greater than $10 \%$ of statistical significance. In addition, it may also be useful for balancing check (after matching) the likelihood ratio test to verify the joint significance of all regressors and pseudo $R^{2}$ analysis (Sianesi, 2004; Amaral et al., 2003; Caliendo and Kopeinig, 2008; Leuven and Sianesi, 2015) 15. These tests assume the null hypothesis that the covariate average of the analyzed groups are statistically equal. If, after this procedure, the matched sample is not balanced, a new specification of covariates must be carried out during the estimation of a new vector of propensity scores (Heinrich et al., 2010).

\subsection{Difference-in-Differences (DID) method}

If a panel data is available, as is in our case, it allows to evaluate the impact of an intervention by using the Difference-in-Differences (DID) method. This approach calculates the effect of treatment of treated and untreated units in time periods, before and after the intervention (Ravallion, 2007). Thus, the DID has two additional advantages compared to the PSM: 1) it captures treatment differences between periods and between treated and control units; and 2) this technique also allows to control unobserved characteristics of treated and untreated group that are assumed to be constant over time (Duflo et al., 2007; Arima et al., 2014).

According to Li et al. (2018), the DID model became very popular in the economics literature and is considered one of the best methods to analyze quasi-natural experiments when is combined with PSM method. The DID approach is also commonly used to evaluate the effects of shocks, such as natural disasters, economic crises, and public policies (Angrist and Pischke, 2009). The hypothesis assumed by the DID is a common trend, which there is a parallel tendency over time of the control and treatment groups in the absence of treatment (Angrist and Pischke, 2009). Thus, it can be assumed that changes between the two groups between the analyzed periods are due only to the treatment (Arima et al., 2014).

\footnotetext{
${ }^{14}$ Further details on these matching techniques can be found in Santos et al. (2016).

${ }^{15}$ For this purpose, it can be used a $\mathrm{Q}-\mathrm{Q}$ (Quantile-Quantile) plot (Ho et al., 2007) and the Hotelling test (Lee, 2013) of the propensity scores of the control and treatment units.
} 
As mentioned, PSM and DID techniques can be combined, controlling with success observable and unobservable characteristics (Khandker et al., 2009; Arima et al., 2014). Thus, the average treatment effect of certification on certified municipality $i$ can be expressed as:

$$
D I D=\left(Y_{i, t}^{T}-Y_{i, t-1}^{T}\right)-\sum_{j \in c} w_{(i, j)}\left(Y_{i, t}^{C}-Y_{i, t-1}^{C}\right)
$$

where, $w_{(i, j)}=$ the weight (using PSM or covariate matching), given the $j-t h$ municipality of the control paired with the $i-t h$ municipality; $t=$ the treatment period (2009, 2010, 2011, 2012, 2013, 2014 and 2015); $t-1$ = the initial reference period (2007); $T=$ the group of treated municipalities, that is, certified by the GBMP; $C=$ the group of control municipalities, non-certified by the GBMP. As shown in section 2, 2008 was the first year of certification for municipalities, however, very few municipalities were certified (approximately 7\%). Thus, we chose to calculate the GBMP impact from the year 2009 and not from 2008 due to not providing sufficient evidence on the impact of the certification.

\subsection{Data}

In order to evaluate the impact of the Green-Blue Municipality certification on the number of cases of diseases related to the contact with air and water pollutants in the municipalities of São Paulo State, the data were obtained from different sources between 2007 and 2015. According to the Epidemiological Surveillance Center "Prof. Alexandre Vranjac" - CVE (2017) ${ }^{16}$ and Martins et al. (2017), the main diseases cataloged with water transmission (Waterborne Diseases - WD) are: Botulism; Cholera; Diarrhea; Leptospirosis; Typhoid fever; Hepatitis A; Rotavirus; and Schistosomiasis. The number of confirmed cases for each of these diseases and for each municipality of the São Paulo State were obtained from the Department of Information Technology of SUS (DATASUS) and CVE ${ }^{17}$. However, the lack of data on cases of Diarrhea and Rotavirus, as well as the low incidence of Cholera (0 cases in 2012) and Botulism (only 5 cases in 2012), limit the analysis to only four types of diseases transmitted by consumption or contact with contaminated water: Leptospirosis; Typhoid fever; Hepatitis A; and Schistosomiasis. Data on waterborne diseases were aggregated into a single variable while $i$ represents the municipality, $t$ is the year, and $\mathrm{j}$ the type of disease, $N C C_{i, t},{ }_{j}$ is the number of confirmed cases of the disease $j$ in the municipality $i$ in year $t$. Then, the aggregation of the number of confirmed cases of waterborne diseases in the municipality $i$ in year $t$ is given by the following indicator $W D_{i, t}$ :

$$
W D_{i, t}=\sum_{j=1}^{n} N C C_{i, t, j}
$$

\footnotetext{
${ }^{16}$ In Portuguese, "Centro de Vigilância Epidemiológica Prof. Alexandre Vranjac (CVE)".

${ }^{17}$ The data used in this study refer only to the public health system.
} 
Data on the number of hospitalizations due to airborne diseases $\left(A D_{i, t}\right)$ in each municipality $i$ in year $t$ were obtained from DATASUS (2017) and consider the Chapter X classified as "Respiratory system diseases J00-J99"18. Nardocci et al. (2013) used the same classification to evaluate the relationship between air pollution and the respiratory diseases in Cubatão (SP). Therefore, the aggregation of Airborne and Waterborne Diseases $\left(A W D_{i, t}\right)$ is given by the expression:

$$
A W D_{i, t}=A D_{i, t}+W D_{i, t}
$$

Figure 2 reports the number of infections related to air and water pollution in São Paulo State from 2006 to $2015^{19}$. In Figure 2a, the notifications of diseases related to air pollution occur in greater number than the cases associated with water pollution. This may reflect the high urbanization degree in São Paulo State and the industrial concentration of the densely populated regions. Nonetheless, the number of reported cases on respiratory diseases declined from approximately 261 thousand in 2006 to roughly 232 thousand in 2015 . The number of airborne diseases reduced expressively between 2007 and 2008. According to CETESB (2010), changes in the air quality are very sensitive to the distribution and intensity of vehicles and industrial emissions.

According to Figure 2b, notifications of diseases related to ingestion or contact with contaminated water showed a significant reduction in the period, from approximately 3,000 cases in 2006 to about 900 cases in 2015 . Larger cities are affected by air and water pollution, while medium and small cities are more vulnerable to water pollution, mainly due to the lack of adequate sanitation, excessive use of agrochemicals in crops and continued droughts, such as the period of extreme dry weather in 2015 that affected almost all municipalities of São Paulo State.

Information on municipalities certified by the GBMP was obtained from the Environmental System of the São Paulo State (SAP) ${ }^{20}$. From this information, a dummy variable is created, 1 for municipalities certified by GBMP and 0 for non-certified municipalities. São Paulo State consist of 645 municipalities and the spatial distribution of the certificated municipalities by GBMP between 2008 and 2015 can be seen in Figure 3.

To select the variables that will compose the logit models in this study, we searched by variables that would be to some extent correlated with pollution and consequent impact on population health. The literature on air and water pollution diseases shows different relationships between economic activity, increased pollution, and effects on

\footnotetext{
${ }^{18}$ The list of diseases related to air and water pollution considered in this analysis is available in Appendix A, Table A.2.

${ }^{19}$ The data on airborne and waterborne diseases take into account the municipality of residence of the individual hospitalized. This procedure eliminates the problem related to pollution exposure in one municipality and hospitalization in another municipality, as in many cases people need to be hospitalized in a different municipality in Brazil due to lack of specialized hospitals in the municipality of residence.

${ }^{20}$ In Portuguese, "Sistema Ambiental Paulista (SAP)”.
} 
Figure 2. Number of reported cases of diseases related to air pollution and water pollution in the São Paulo State between 2006 and 2015

(a)

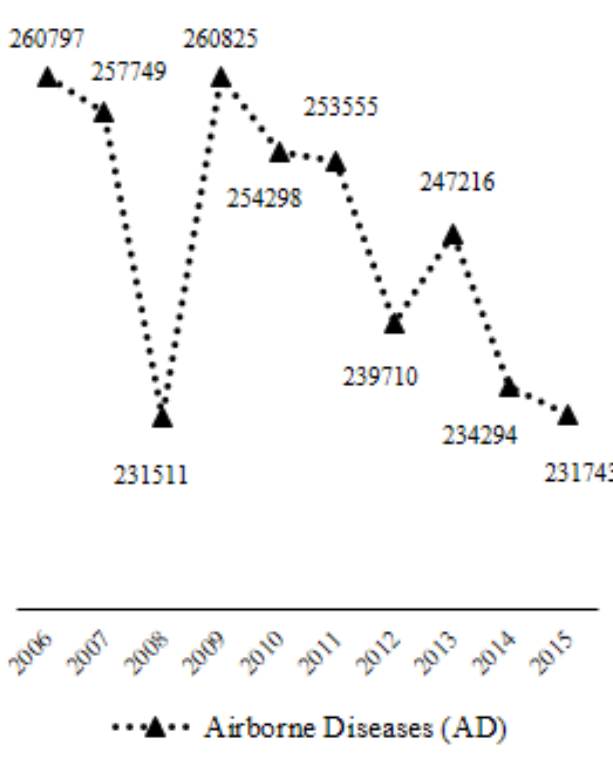

(b)

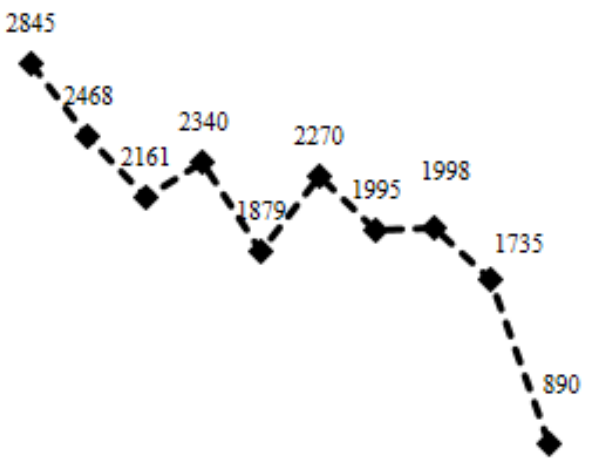

Source: Elaborated by the authors based on data from DATASUS (2017) and CVE (2017).

human health (Oliveira et al., 2013; Carneseca et al., 2012; Yanagi et al., 2012; Nardocci et al., 2013; Habermann et al., 2014).

According to Habermann et al. (2014), accelerated economic growth and urbanization contribute to the increased number of vehicles, a major source of air pollutant emissions, causing adverse health effects, such as greater number of hospitalizations, mortality, and reduction of life expectancy. Oliveira et al. (2013) argue that the longterm exposure to Particulate Matter (PM) ${ }^{21}$, when found in massive quantities in the atmosphere, is related to a reduction in life expectancy and the increase in risk of mortality by cardiopulmonary diseases. In addition, in urban areas, $\mathrm{SO}_{2}$ emissions, the main inorganic component of $P M_{2.5}$, are often extremely high, contributing more to the formation of sulfuric acid $\left(\mathrm{H}_{2} \mathrm{SO}_{4}\right)$, which has inflammatory effects on humans and animals, mainly in the lungs, aggravating health problems (Oliveira et al., 2013).

The main emitting sources of PM into the atmosphere are the combustion of fossil fuels and the burning of biomass ${ }^{22}$, such as sugarcane. Thus, São Paulo State constitutes an important source of PM emissions, since it has many industries and

\footnotetext{
${ }^{21}$ According to Oliveira et al. (2013), Particulate Matter (PM) can be classified in: a) $P M_{0.1}$, called ultrafine particulate matter, which has an aerodynamic diameter smaller than $0.1 \mu \mathrm{m}$; b) $P M_{2.5}$, fine particles, with aerodynamic diameter smaller than $2.5 \mu \mathrm{m}$; and c) $P M_{10}$, the coarse particles, with aerodynamic diameter smaller than $10 \mu \mathrm{m}$.

${ }^{22}$ According to Oliveira et al. (2013), with the burning of sugarcane biomass in the southeastern region, concentrations of materials such as Zinc $(\mathrm{Zn})$, Iron $(\mathrm{Fe})$, Lead (Pb), Copper $(\mathrm{Cu})$, Mercury $(\mathrm{Hg})$ are found as elemental composition of $P M_{2.5}$. On the other hand, possibly the mining activity is responsible for Hg concentrations.
} 
Figure 3. Spatial distribution of the certificated municipalities by GBMP in São Paulo State between 2008 and 2015

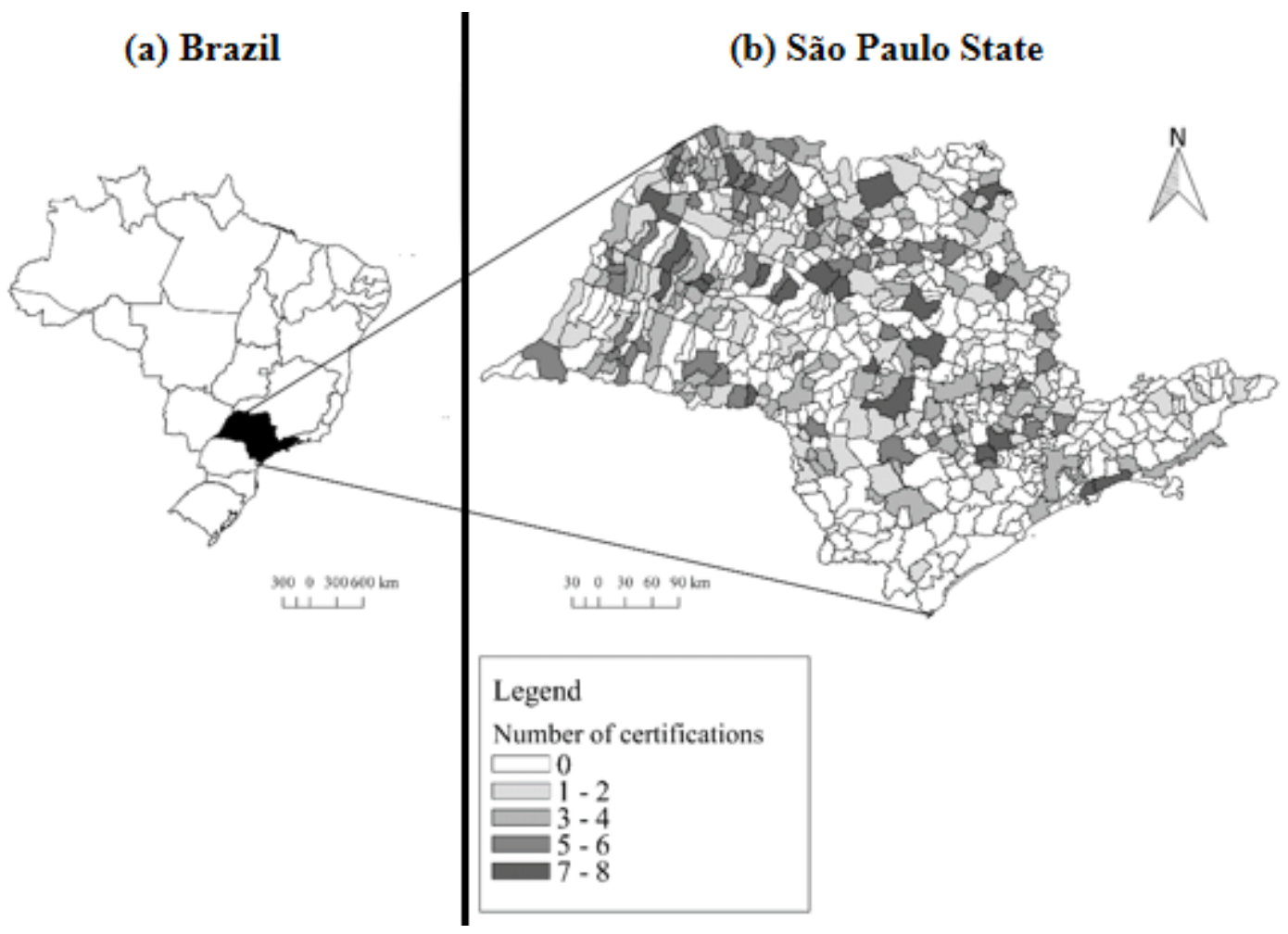

Source: Elaborated by the authors based on data from SAP (2016).

an expressive fleet of vehicles, mainly in the metropolitan areas of the state (Oliveira et al., 2013). Yanagi et al. (2012) verified that PM influenced the incidence of some types of cancer (skin, lung, thyroid, larynx, and bladder) and increased deaths. Additionally, Nardocci et al. (2013), found a strong relationship between the increase in PM emissions and the number of hospitalizations for general respiratory diseases in a highly industrialized region in the municipality of Cubatão (in the state of São Paulo). In the city of São Paulo, the regions with lower levels of economic development have small levels of vehicular traffic, showing lower rates of air pollution, while individuals with higher income live in areas with greater vehicular traffic and, therefore, more air pollution is observed (Habermann et al., 2014).

Hence, variables that measure economic growth, urbanization, industrialization, and municipal fleet are relevant to the decision to participate in a program to control the emission of pollutants. Based on these arguments, we selected economic and control variables for the composition of the Logit model, such as the Gross Domestic Product (GDP), the Human Development Index (HDI) and the urban population for each municipality for every year of our analysis. We also considered industry and agriculture participation in the added value because it is assumed that pollution levels occur more in more industrialized cities and with greater agriculture activities. The choice of variables on "concessionaires" is justified by the possible differences in service quality of provision among the water companies. Fleet variables (automobiles, 
trucks, motorcycles, and micro-buses) were selected because of their collaboration in increasing respiratory diseases due to pollutant emissions of vehicles. The choice of the urbanization degree is because an elevated urbanization level can generate greater pollution and a significant impact on diseases related to water and air quality. Table 2 shows the summary of the selected variables.

Table 2. Variable definitions and their sources

\begin{tabular}{|c|c|c|}
\hline Variable & Description & Source \\
\hline daa & $\begin{array}{l}\text { Aggregation of the number of hospitalizations due to respiratory diseases } \\
\text { (with influenza) and cases of waterborne diseases for the years from } 2001 \\
\text { to } 2015\end{array}$ & $\begin{array}{l}\text { DATASUS (2017) } \\
\text { and CVE (2017) }\end{array}$ \\
\hline treat & $\begin{array}{l}\text { Dummy: municipalities certified by Green-Blue Municipality Program } \\
\text { (GBMP). The variable assumes value } 1 \text { for the municipality certified by } \\
\text { GBMP and } 0 \text { if not certified, from } 2009 \text { to } 2015 \text {. }\end{array}$ & SAP (2016) \\
\hline ln_gdp & $\begin{array}{l}\text { Gross Domestic Product from } 2009 \text { to } 2014 \text {. The values are in Reais (R\$) } \\
\text { of } 2015 \text {. }\end{array}$ & SEADE (2017) \\
\hline popurban & Municipal urban population from 2009 to 2015. & \\
\hline part_ind_av & $\begin{array}{l}\text { Share of the added value of the industrial sector in relation to the total } \\
\text { added value in the municipality from } 2009 \text { to } 2014 \text {. The added value } \\
\text { is characterized as the value that the activity adds to the } \\
\text { goods and services consumed in its production process. }\end{array}$ & \\
\hline part_agro_av & $\begin{array}{l}\text { Share of the added value of the agricultural sector in relation to the total } \\
\text { added value in the municipality from } 2009 \text { to } 2014\end{array}$ & \\
\hline aut & Fleet of automobiles in the municipality from 2009 to 2015. & \\
\hline buses & Fleet of buses in the municipality from 2009 to 2015 . & \\
\hline trucks & Truck fleet in the municipality from 2009 to 2015 . & \\
\hline motorcycle & Motorcycle fleet in the municipality from 2009 to 2015. & \\
\hline micro-buses & Fleet of micro-buses in the municipality from 2009 to 2015 . & \\
\hline urb & $\begin{array}{l}\text { Share of the urban population in relation to the total population of } \\
\text { the municipality from } 2009 \text { to } 2015 \text {. }\end{array}$ & \\
\hline hdi & Firjan Municipal Development Index from 2009 to 2013. & FIRJAN (2015) \\
\hline c_dae & $\begin{array}{l}\text { Dummy: Department of Water and Sewage* from } 2009 \text { to } 2015 . \\
\text { The value } 1 \text { indicates that the DAE is the concessionary company } \\
\text { and the value } 0 \text { if not }\end{array}$ & $\begin{array}{l}\text { CETESB (2007) } \\
\text { CETESB (2008) } \\
\text { CETESB (2009a) }\end{array}$ \\
\hline c_ch & $\begin{array}{l}\text { Dummy: City Hall from } 2009 \text { to } 2015 \text {. The value } 1 \text { indicates that } \\
\text { the prefecture is the concessionaire and the value } 0 \text { if not. }\end{array}$ & $\begin{array}{l}\text { CETESB (2010) } \\
\text { CETESB (2011) }\end{array}$ \\
\hline c_saae & $\begin{array}{l}\text { Dummy: Autonomous Water and Sewage Service** (SAAE) from } \\
2009 \text { to } 2015 \text {. The value } 1 \text { indicates that the SAAE is the concessionary } \\
\text { company and the value } 0 \text { if not. }\end{array}$ & $\begin{array}{l}\text { CETESB (2012) } \\
\text { CETESB (2013) } \\
\text { CETESB (2014) }\end{array}$ \\
\hline c_sae & $\begin{array}{l}\text { Dummy: Secretariat of Water and Sewage*** (SAE) from } 2009 \text { to } 2015 . \\
\text { The value } 1 \text { indicates that the SAE is the concessionaire and the } \\
\text { value } 0 \text { if not. }\end{array}$ & $\begin{array}{l}\text { CETESB (2015) } \\
\text { CETESB (2016) }\end{array}$ \\
\hline c_sabesp & $\begin{array}{l}\text { Dummy: São Paulo State Basic Sanitation Company**** (SABESP) } \\
\text { from } 2009 \text { to } 2015 \text {. The value } 1 \text { indicates that SABESP is the } \\
\text { concessionaire and value } 0 \text { if not. }\end{array}$ & \\
\hline c_other & $\begin{array}{l}\text { Dummy: Other concessionaires from } 2009 \text { to } 2015 \text {. The value } 1 \text {. } \\
\text { indicates that other concessionaires act in the municipality and } \\
\text { the value } 0 \text { if not. }\end{array}$ & \\
\hline
\end{tabular}

Source: Elaborated by the authors.

Note: * In Portuguese, "Departamento de Água e Esgoto (DAE)". ** In Portuguese, "Serviço Autônomo de Água e Esgoto (SAAE)”. *** In Portuguese, “Secretaria de Água e Esgoto (SAE)”. **** In Portuguese, "Companhia de Saneamento Básico do Estado de São Paulo (SABESP)”. 


\section{Results}

The analysis of possible impact of GBMP certification requires to find a control group with similar economic and social characteristics to the treated group, differing only from the fact of not receiving the intervention. Based on the characteristics that may influence the probability of joining the program, it is possible to identify the comparable municipalities among those that did not join the program (Rosenbaum and Rubin, 1983). Given the certification, the impact analysis is carried out year by year, the mean of the baseline adopted for the pre-match group also changes year by year. In the year $t$, the control group is limited to those municipalities that have not obtained certification in any previous period. In general, 12 variables captured the differences between groups (ln_gdp, hdi, popurban, c_sae, part_ind_av, part_agro_av, aut, buses, trucks, motorcycles, microbuses and urb), when different years are taken into an account ${ }^{23}$.

The second step in our analysis of the GBMP certification on the number of notifications of diseases related to water and air quality was the estimation of a Logit model of the municipality, certificated or not by the program. The results of this model can be seen in Table 3.

The null hypothesis that all coefficients are equal to zero was rejected at the significance level of $1 \%$, showing a robustness of the model considering the coefficients together. The statistically significant coefficients are: hdi, popurban, c_sae, c_sabesp, part_ind_av, part_agr_av, aut, buses, motorcycles, microbuses, and urb (see Table 2 for variable definitions). In general, the results indicate that hdi, agricultural participation in the added value, variable on "concessionaires" (SABESP or SAE), number of automobiles, motorcycles, microbuses, and the urbanization degree have a positive relation with the probability of participation in the program. However, urban population, number of buses in the municipality and industry participation in the added value have a negative impact, i.e., the higher the value of these variables, the lower the probability of the municipality to join in the GBMP. Figure 4 shows the probability distribution of participating in GBMP for each group (participants and non-participants) before the matching. There is no overlap between the two groups. Thus, the treatment and control groups are not statistically comparable in terms of observable characteristics. Therefore, PSM approach is necessary.

As described in the methodology section, propensity scores generated by the logit model are used by pairing the treatment with the control units and find the best match. Afterward, balancing tests verify if there are still differences of the observable characteristics that existed between the two groups after the matching. It is expected to find no difference between two groups (balanced samples). The balancing statistics (standardized bias and p-values) for all algorithms considered are presented in Ap-

\footnotetext{
${ }^{23}$ The values of pre-match group mean tests for municipalities certificated by GBMP versus noncertificated by GBMP from 2009 to 2015 are not reported for convenience. The tables concerning these results can be request to authors.
} 
pendix B of this study. For all years, most of the covariates used for the construction of the matched samples based on propensity scores are balanced at the significance level of $1 \%$.

Table 3. Logit Model Results

\begin{tabular}{|c|c|c|c|c|c|c|c|}
\hline Variables & 2009 & 2010 & 2011 & 2012 & 2013 & 2014 & 2015 \\
\hline \multirow[t]{2}{*}{$\operatorname{ln\_ gdp}$} & -0.00527 & 0.08721 & 0.19218 & -0.02290 & 0.09076 & -0.09776 & -0.03103 \\
\hline & $(0.1538)$ & $(0.15912)$ & $(0.16127)$ & (0.1324) & (0.18933) & $(0.14368)$ & (0.14033) \\
\hline \multirow[t]{2}{*}{ hdi } & 2.51606 & 1.54860 & 3.69466* & $5.66981^{* *}$ & $8.89625^{* *}$ & $7.28373^{* * *}$ & $10.55384^{* * *}$ \\
\hline & $(2.00404)$ & (1.91387) & (2.16902) & $(2.41174)$ & (3.5627) & $(2.74414)$ & (3.13408) \\
\hline \multirow[t]{2}{*}{ popurban } & $-0.00005^{* * *}$ & $-0.00006^{* * *}$ & $-0.00006^{* * *}$ & $-0.00002^{*}$ & $-0.00006^{* * *}$ & $-0.00005^{* * *}$ & $-0.00003^{* * *}$ \\
\hline & $(0.00001)$ & $(0.00002)$ & $(0.00002)$ & $(0.00001)$ & $(0.00002)$ & $(0.00001)$ & $(0.00001)$ \\
\hline \multirow[t]{2}{*}{ c_dae } & -0.10691 & 0.07374 & -0.34666 & -0.43664 & 0.41987 & 0.12470 & -0.63556 \\
\hline & $(0.60715)$ & $(0.62482)$ & (0.56141) & (0.58437) & $(0.75627)$ & $(0.56861)$ & (0.59118) \\
\hline \multirow[t]{2}{*}{ c_ch } & 0.37755 & 0.44449 & 0.05566 & -0.32968 & 0.27361 & 0.00464 & -0.46084 \\
\hline & (0.51191) & $(0.53624)$ & $(0.46977)$ & (0.43739) & $(0.66286)$ & $(0.48342)$ & $(0.45285)$ \\
\hline \multirow[t]{2}{*}{ c_saae } & 0.25458 & 0.56352 & 0.10811 & -0.41267 & 0.39041 & -0.12463 & -0.40921 \\
\hline & (0.59927) & $(0.6052)$ & (0.55492) & $(0.51824)$ & (0.69953) & $(0.53882)$ & (0.50186) \\
\hline \multirow[t]{2}{*}{ c_sae } & 0.86897 & $1.24202^{*}$ & $1.09266^{*}$ & 0.66113 & 0.63708 & 0.06343 & -0.77885 \\
\hline & $(0.69611)$ & $(0.68044)$ & (0.63267) & $(0.60277)$ & $(0.81966)$ & (0.69591) & (0.87032) \\
\hline \multirow[t]{2}{*}{ c_sabesp } & $0.97600^{* *}$ & $0.98837^{* *}$ & 0.56573 & -0.01156 & 0.69154 & 0.39221 & -0.07326 \\
\hline & $(0.47614)$ & $(0.49217)$ & $(0.42753)$ & $(0.3782)$ & (0.58813) & $(0.42226)$ & $(0.37917)$ \\
\hline \multirow[t]{2}{*}{ part_ind_av } & -0.00400 & -0.00854 & $-0.01873^{*}$ & $-0.01808^{* *}$ & -0.02119 & -0.01553 & $-0.01946^{*}$ \\
\hline & (0.00949) & $(0.01041)$ & (0.00992) & $(0.00924)$ & (0.01398) & $(0.01042)$ & (0.01064) \\
\hline \multirow[t]{2}{*}{ part_agr_av } & $0.02256^{* * *}$ & $0.02138^{* *}$ & $0.02510^{* * *}$ & 0.00792 & $0.02040^{*}$ & 0.00155 & 0.00500 \\
\hline & $(0.00814)$ & (0.00899) & (0.00966) & (0.0094) & $(0.01127)$ & $(0.01031)$ & $(0.01146)$ \\
\hline \multirow[t]{2}{*}{ aut } & 0.00007 & $0.00011^{* * *}$ & $0.00010^{* *}$ & -0.00001 & $0.00012^{* *}$ & $0.00008^{* *}$ & $0.00007^{* *}$ \\
\hline & $(0.00004)$ & $(0.00004)$ & $(0.00004)$ & $(0.00004)$ & $(0.00005)$ & $(0.00004)$ & (0.00003) \\
\hline \multirow[t]{2}{*}{ buses } & -0.00083 & $-0.00273^{*}$ & $-0.00211^{*}$ & -0.00112 & $-0.00339^{* *}$ & $-0.00281^{* *}$ & $-0.00253^{* *}$ \\
\hline & $(0.00122)$ & $(0.00156)$ & $(0.00113)$ & (0.0008) & $(0.00168)$ & $(0.00124)$ & (0.00115) \\
\hline \multirow[t]{2}{*}{ trucks } & 0.00004 & 0.00018 & 0.00005 & -0.00001 & 0.00031 & 0.00033 & 0.00030 \\
\hline & $(0.00032)$ & (0.00029) & $(0.00021)$ & (0.00016) & $(0.00025)$ & $(0.00022)$ & $(0.00021)$ \\
\hline \multirow[t]{2}{*}{ motorcycles } & $0.00010^{* *}$ & $0.00009^{* *}$ & $0.00007^{*}$ & 0.00003 & $0.00007^{* *}$ & $0.00006^{*}$ & 0.00004 \\
\hline & $(0.00005)$ & $(0.00004)$ & (0.00004) & $(0.00003)$ & $(0.00004)$ & $(0.00004)$ & (0.00003) \\
\hline \multirow[t]{2}{*}{ microbuses } & 0.00033 & 0.00028 & $0.00035^{*}$ & 0.00032 & -0.00003 & 0.00009 & -0.00003 \\
\hline & $(0.00026)$ & $(0.00018)$ & $(0.00018)$ & (0.00019) & $(0.00018)$ & $(0.00014)$ & (0.00013) \\
\hline \multirow[t]{2}{*}{ urb } & $0.03118^{* * *}$ & $0.03372^{* * *}$ & $0.03379^{* * *}$ & $0.01959^{* *}$ & $0.03923^{* *}$ & $0.04056^{* * *}$ & $0.02639^{* * *}$ \\
\hline & (0.00848) & (0.00909) & (0.00998) & (0.00939) & (0.019) & (0.01305) & (0.01278) \\
\hline \multirow[t]{2}{*}{ constant } & $-6.06171^{* * *}$ & $-6.73143^{* * *}$ & $-9.03465^{* * *}$ & $-6.28060^{* * *}$ & $-13.16252^{* * *}$ & $-8.64996^{* * *}$ & $-10.51291^{* * *}$ \\
\hline & $(2.14895)$ & $(2.22422)$ & (2.30438) & $(2.04442)$ & (3.61148) & $(2.50227)$ & (2.76038) \\
\hline $\mathrm{N}$ & 516 & 493 & 512 & 489 & 423 & 478 & 468 \\
\hline Pseudo $\mathrm{R}^{2}$ & 0.101 & 0.115 & 0.131 & 0.101 & 0.156 & 0.136 & 0.142 \\
\hline Wald & $48.53^{* * *}$ & $54.46^{* * *}$ & $67.28^{* * *}$ & $41.88^{* * *}$ & $36.07^{* * *}$ & $47.80^{* * *}$ & $54.99^{* * *}$ \\
\hline
\end{tabular}

Source: Elaborated by the authors.

Note: Asterisks denote statistical significance at $1 \%\left({ }^{* * *}\right), 5 \%\left({ }^{* *}\right)$, or $10 \%\left({ }^{*}\right)$ level. 
Figure 4. Distribution of probability of participating in GBMP before pairing

(a)

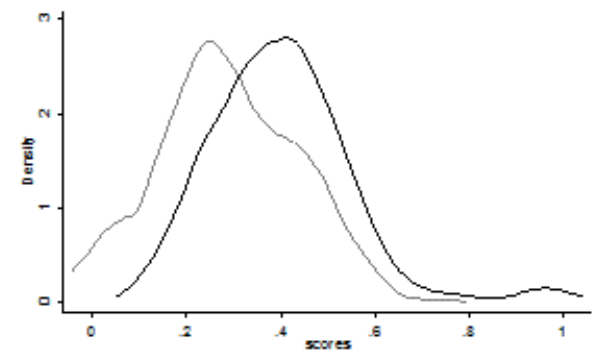

(c)

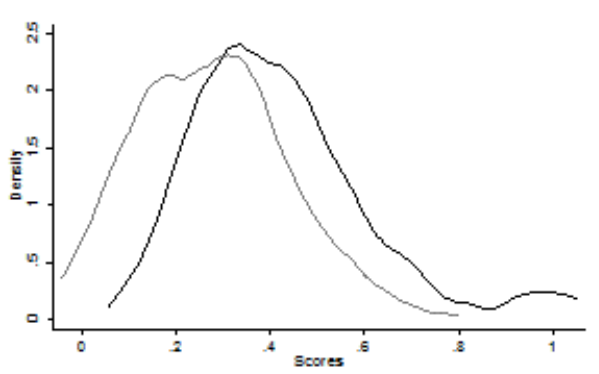

(e)

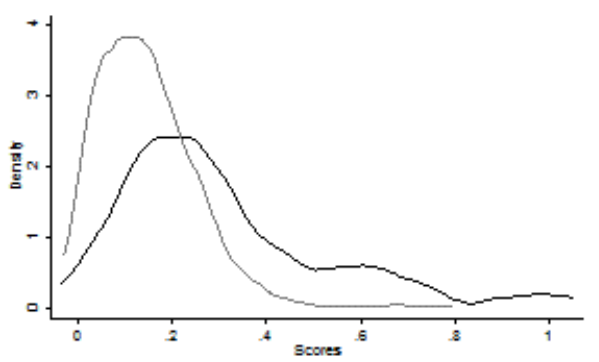

(b)

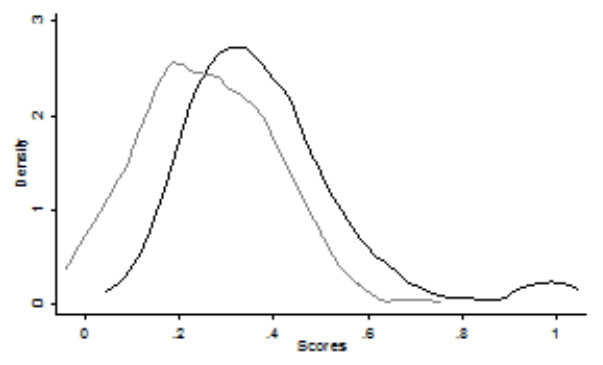

(d)

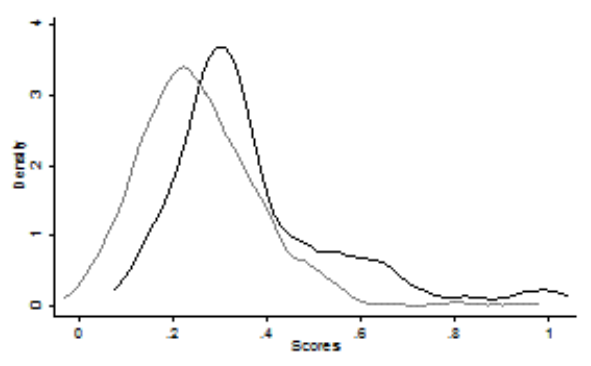

(f)

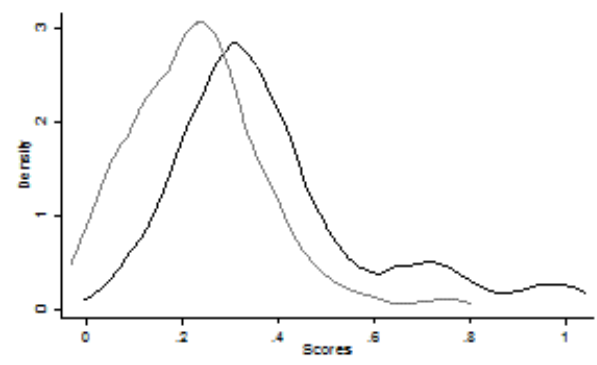

(g)

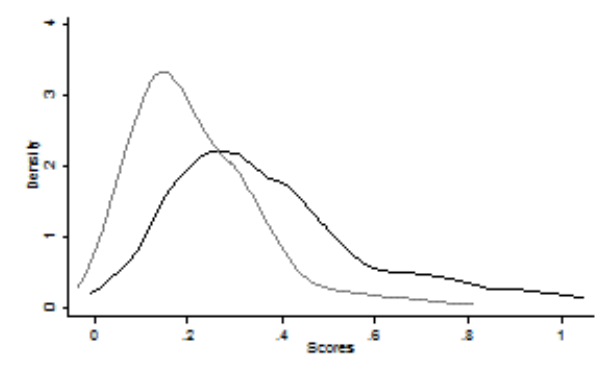

Legend

Control Group - Non-Certificated by GBMP

Treatment Group - Certificated by GBMP

Source: Elaborated by the authors using the STATA v. 13 software. 
The estimated impact of GBMP certification on the number of cases of diseases related to water and air quality is shown in Table 4. In summary, considering first the DID estimator without matching (Naïve estimator), followed by all matching techniques (DID-PSM) adopted, our results indicate no statistically significant reduction in the number of cases of diseases related to air and water quality in municipalities certified by GBMP in Sao Paulo State. The results of the kernel matching for 2012 and 2015 and the nearest neighbor with a caliper for 2012 are the only two exceptions.

Table 4. GBMP certification effect on the number of notifications of water and air diseases in the period of 2009-2015

\begin{tabular}{lccccccc}
\hline \hline Matching & $2009-$ & $2010-$ & $2011-$ & $2012-$ & $2013-$ & $2014-$ & $2015-$ \\
Techniques & 2007 & 2007 & 2007 & 2007 & 2007 & 2007 & 2007 \\
\hline No Matching & 5.906 & -11.295 & 2.293 & -17.076 & 9.156 & -1.697 & -10.448 \\
(Naïve Estimator) & $(15.481)$ & $(20.720)$ & $(18.576)$ & $(29.668)$ & $(26.077)$ & $(20.467)$ & $(21.708)$ \\
& & & & & & & \\
Nearest neighbor & -18.583 & -2.949 & 0.452 & -8.380 & -35.803 & -13.653 & -38.411 \\
without caliper & $(11.208)$ & $(12.289)$ & $(11.746)$ & $(15.949)$ & $(21.121)$ & $(15.403)$ & $(20.568)$ \\
& & & & & & & \\
Nearest neighbor & -9.644 & -7.785 & -0.598 & $-70.893^{* * *}$ & -14.368 & -15.786 & -39.706 \\
with caliper & $(13.118)$ & $(13.567)$ & $(11.129)$ & $(18.280)$ & $(25.793)$ & $(17.986)$ & $(20.310)$ \\
& & & & & & & \\
Kernel $€$ & -10.500 & -10.182 & -1.802 & $-74.298^{* * *}$ & -13.082 & -20.142 & $-39.338^{* * *}$ \\
& $(13.418)$ & $(16.373)$ & $(14.904)$ & $(18.686)$ & $(25.721)$ & $(18.132)$ & $(19.531)$ \\
& & & & & & & \\
Matching & 2.369 & 12.841 & 18.720 & -10.574 & 7.827 & 2.515 & -5.833 \\
covariate & $(13.445)$ & $(32.503)$ & $(18.027)$ & $(40.715)$ & $(27.968)$ & $(22.784)$ & $(27.554)$ \\
\hline Observations & 516 & 493 & 512 & 489 & 423 & 478 & 468 \\
Certified & 168 & 145 & 164 & 141 & 75 & 130 & 120 \\
Control & 348 & 348 & 348 & 348 & 348 & 348 & 348 \\
\hline \hline
\end{tabular}

Source: Elaborated by the authors.

Note: ${ }^{\dagger}$ the caliper size is defined as a $1 / 4$ of the standard deviation of the propensity score

(Rosenbaum and Rubin, 1983); $€$ optimum bandwidth is calculated according to the Silverman

(1986) rule. Error deviation between parentheses. Asterisks denote statistical significance at 1\%.

This result also suggests that, even after eight years of existence of GBMP certification, no substantial positive externalities, such as a significant reduction in the number of cases of diseases associated with air and water pollution released into the environment have been verified for our health indicators. Our result appears to be in line with Gehrsitz (2017), who investigated the effect of low pollution areas in Germany on air quality and the impact on children's health. Although the results indicate that the adoption of more restrictive low emission areas contributed to reducing pollution levels, the reduction has not been sufficient to have substantial effects on improving the health of children.

On the other hand, the study of Li et al. (2018) found significant outcomes for a similar analysis developed in China. Li et al. (2018) studied the effects of the Environmental Non-Governmental Organizations (ENGOs). The ENGOs policies embraces 
a set of environmental issues, such as environmental education, biodiversity, energy conservation, water and air pollution, and projects of dams and hydropower. In China, a central ENGO called Institute of Public and Environmental Affairs (IPEA) designs yearly a "pollution map" and calculates the "Pollution Information Transparency Index" (PITI) to evaluate eight categories of environmental policies in the country ${ }^{24}$. After the calculation of PITI, cities with a better pollution control are ranked on a PITI list. Their study also adopted the Difference-in-Differences (DID) and the Propensity Score Matching (PSM) methods to check robustness of the estimates. The data used pollution information for 109 cities as treated group i.e., the cities on the PITI list, and 171 cities in the control group between 2003 and 2014.

The study of Li et al. (2018) showed a significantly negative impact of ENGOs on pollution emissions in the cities on the PITI list from a naïve DID approach when compared with the non-PITI list cities. However, one of the caveats of their preliminary analysis is that the cities were chosen by ENGOs to receive an environmental management due to serious pollution, and this fact can be some source of bias (case of uncertain if PITI list is random) in the results. Therefore, the authors used the PSM-DID with kernel matching method to test robustness of the DID results. The results of the PSM-DID model also corroborate that the ENGOs have a negative impact on the pollution level in the municipalities with this type of environmental policy management.

In our study, we evaluate the effects of the GBMP certification on the number of hospitalization due to water and air quality in the municipalities of São Paulo State. However, the pre-certification effect is not captured by our models given municipalities need to do their homework in order to improve the environmental quality and be possibly certified by the program. Thus, the present study can be classified only as a partial analysis of the certification effects and results are limited. Another important limitation is also the Environmental Assessment Index (EAI) which we adopted, it changed during the period analyzed, becoming more rigorous. These two limitations can affect our analysis, resulting, possibly, in an underestimation of the true effects of the GBMP on the number of hospitalizations due to air and water quality.

The non-corroboration of the initial hypothesis of this study can be explained by some reasons. First, due to the short time of GBMP implementation, significant changes in conducting the municipal environmental policy have not yet been observed properly. Perhaps, there are other ways. Second, the GBMP is practically unknown by the population, resulting in low visibility of the program, which discourages a greater number of adhesions by local officials of the municipalities. Third, there is also a large set of barriers required for the entry and possible certification in the GBMP, making

\footnotetext{
${ }^{24}$ According to Li et al. (2018), for each category, it is attributed a score and the maximum final summation is 100. The eight categories of PITI are: the records of enterprise violations; the results of "enforcement campaigns" against polluting facilities; clean production audit information; enterprise environmental performance ratings; the disposition of verified petitions and complaints; environmental impact assessment reports; project completion approvals, discharge fee data; and responses to public information requests.
} 
the commitment to the program more difficult. Moreover, there is also an incomplete system of economic benefits for municipalities that join the program. Hence, from the municipal management point of view, the benefits may not overcome the costs incurred to achieve GBMP certification. Forth, the effects of GBMP certification on the number of cases of diseases related to air and water quality are underestimated due to the lack of municipal information on waterborne diseases, such as Diarrhea and Rotavirus. For Diarrhea, a possible explanation would be the self-medication and the absence of accessing the Unified Health System (SUS) by the individuals since the population undervalue the disease.

According to Li et al. (2018), in China there is a political dispute, which encourage the desire for accelerated GDP growth in local governments, resulting in several environmental problems. In Brazil, mayors are elected every four years; thus, the political dispute is a key factor that can affect the adherence to GBMP. The change of political management (mayors) can influence adhesion to the GBMP and possible certification. On the other hand, non-certification in one year may discourage voluntary membership in the next year, avoiding the progress of the public policy and consequently generating no significant effect on individual's health in each municipality. This is the fifth reason for no-effective results of GBMP, but this is left for future studies. Even thus, Joly (2017) emphasizes problems associated to environmental public policy in Brazil, such as the lack of transparency in municipal accounts, local political power, and the corruption. When combined, these factors can affect the environmental sustainability, resulting in weak enforcement of ecological regulations, and consequently, increasing the pollution and its negative effects on human health. The union of these elements can be listed as one of the sixth factors influencing the results of GBMP certification.

In Brazil, GBMP discloses the list with all municipalities that joined in the program, but environmental information on municipalities that were not running for a GBMP certificate is not publicized, contributing to the perpetuation of environmental standards of each non-participating municipality. Similarly, Li et al. (2018) pointed that, in China, local governments do not publicize environmental information on cities with less pollution control because of a consciousness that "local shame should not be made public".

Despite all the factors that contribute to the underestimation of the certification effects, there are some significant impacts observed in 2012 considering the kernel and nearest neighbor with the caliper technique. In 2012, the certified municipalities registered a decrease on the observed number of hospitalizations due to water and air quality considering both models (approximately 70 fewer cases), as presented in Table 4. In 2015, the municipalities certified by the GBMP registered, on average, 39 fewer cases if compared to non-certified municipalities (kernel paring method). These results suggest that the program is beginning to present effects on human health. Nevertheless, future studies should investigate if there will be major and significant 
effects of certification on cases of diseases in the coming years.

\subsection{Robustness check}

In this section, we validate our previous results including a robustness check analysis. We performed three additional tests: 1) we excluded influenza from the group of diseases related to air pollution, as a way of verifying whether our previous sample overestimated or underestimated the policy results, 2) we used a placebo estimate using the result variable as the number of hospitalizations due assaults ${ }^{25}$ and 3) we estimate the effect of the program on diseases related to air and water quality using the method of Generalized Difference-in-Differences (GDD).

The effects evaluated in the first test are shown in Table 5. As in our main results, effects are observed in the year 2012, for the kernel and nearest neighbor pairing techniques without caliper, however, such effect is not found in 2015. These results reveal that excluding cases of influenza diseases from the sample does not significantly alter the outcomes found previously, corroborating the effects of GBMP certification in our analysis.

Table 5. GBMP certification effect on the number of notifications of water and air diseases (except influenza) in the period of 2009-2015

\begin{tabular}{lccccccc}
\hline \hline Matching & $2009-$ & $2010-$ & $2011-$ & $2012-$ & $2013-$ & $2014-$ & $2015-$ \\
Techniques & 2007 & 2007 & 2007 & 2007 & 2007 & 2007 & 2007 \\
\hline No Matching & 0.518 & -14.877 & 1.163 & -16.652 & 0.042 & -7.116 & -16.181 \\
(Naïve Estimator) & $(12.805)$ & $(17.072)$ & $(14.516)$ & $(24.763)$ & $(21.799)$ & $(17.160)$ & $(18.495)$ \\
& & & & & & & \\
Nearest neighbor & -20.153 & -4.297 & -1.032 & -11.015 & -40.338 & -12.793 & -39.170 \\
without caliper & $(10.998)$ & $(12.246)$ & $(11.837)$ & $(16.253)$ & $(21.063)$ & $(15.382)$ & $(20.799)$ \\
& & & & & & & \\
Nearest neighbor & -12.703 & -9.273 & -2.671 & $-77.856^{* * *}$ & -25.284 & -16.814 & -42.638 \\
with caliper ${ }^{\dagger}$ & $(10.916)$ & $(13.667)$ & $(11.333)$ & $(15.404)$ & $(22.074)$ & $(15.672)$ & $(17.938)$ \\
& & & & & & & \\
Kernel ${ }^{€}$ & -13.508 & -12.135 & -3.907 & $-81.044^{* * *}$ & -23.111 & -21.502 & -42.554 \\
& $(1.368)$ & $(15.542)$ & $(12.765)$ & $(16.064)$ & $(22.079)$ & $(15.865)$ & $(17.383)$ \\
Matching & -2.518 & 5.793 & 22.335 & -5.326 & 2.387 & -0.546 & -9.867 \\
covariate & $(13.689)$ & $(21.241)$ & $(14.900)$ & $(34.887)$ & $(28.338)$ & $(23.127)$ & $(27.808)$ \\
\hline Observations & 516 & 493 & 512 & 489 & 423 & 478 & 468 \\
Certified & 168 & 145 & 164 & 141 & 75 & 130 & 120 \\
Control & 348 & 348 & 348 & 348 & 348 & 348 & 348 \\
\hline \hline
\end{tabular}

Source: Elaborated by the authors.

Note: ${ }^{\dagger}$ the caliper size is defined as a $1 / 4$ of the standard deviation of the propensity score Rosenbaum and Rubin (1983); ${ }^{€}$ optimum bandwidth is calculated according to the Silverman (1986) rule. Error deviation between parentheses. Asterisks denote statistical significance at 1\%.

Table 6 reports our second test, in which we verified the placebo effect of GBMP

\footnotetext{
${ }^{25}$ Table A.2 also presents the full list of all aggression types considered in the analyses.
} 
certification on hospitalizations due to assaults. The results show possible effects when considering the naïve estimator for the years 2013 to 2015. But, using the pairing techniques, we did not find any relevant impacts on the result variable. The effects found in the naïve estimator may be related to the fact that this estimator is not combined with the PSM, which aims to compare comparable groups, based on observable characteristics. Therefore, the combination of the two methods brings more reliable results.

Table 6. GBMP certification effect on the number of hospitalizations due assaults in the period of 2009-2015

\begin{tabular}{|c|c|c|c|c|c|c|c|}
\hline $\begin{array}{l}\text { Matching } \\
\text { Techniques }\end{array}$ & $\begin{array}{c}2009- \\
2007\end{array}$ & $\begin{array}{c}2010- \\
2007\end{array}$ & $\begin{array}{c}2011- \\
2007\end{array}$ & $\begin{array}{c}2012- \\
2007\end{array}$ & $\begin{array}{c}2013- \\
2007\end{array}$ & $\begin{array}{c}2014- \\
2007\end{array}$ & $\begin{array}{c}2015- \\
2007\end{array}$ \\
\hline No Matching) & $-2,270$ & 2,143 & $-2,729$ & $-4,944$ & $-22,211^{* * *}$ & $-13,488^{* * *}$ & $-14,930 * * *$ \\
\hline (Naïve Estimator & $(2,020)$ & $(1,949)$ & $(4,326)$ & $(6,167)$ & $(8,151)$ & $(6,347)$ & $(6,560)$ \\
\hline Nearest neighbor & $-0,933$ & $-0,007$ & $-2,426$ & $-12,343$ & $-2,887$ & $-3,017$ & $-3,098$ \\
\hline without caliper & $(0,916)$ & $(1,000)$ & $(2,307)$ & $(8,103)$ & $(6,198)$ & $(3,844)$ & $(3,824)$ \\
\hline Nearest neighbor & $-0,526$ & $-1,764$ & $-2,310$ & $-2,447$ & $-4,676$ & $-4,504$ & $-4,002$ \\
\hline with caliper ${ }^{\dagger}$ & $(0,850)$ & $(1,009)$ & $(2,328)$ & $(3,003)$ & $(5,261)$ & $(3,458)$ & $(3,659)$ \\
\hline \multirow[t]{2}{*}{ Kernel $1^{€}$} & $-0,511$ & $-1,272$ & $-2,422$ & $-10,883$ & $-4,826$ & $-4,646$ & $-3,947$ \\
\hline & $(0,892)$ & $(1,014)$ & $(2,348)$ & $(8,137)$ & $(5,190)$ & $(3,419)$ & $(3,601)$ \\
\hline Matching & $-5,804$ & 1,972 & $-2,915$ & $-1,681$ & $-21,440$ & $-10,346$ & $-15,525$ \\
\hline covariate & $(2,768)$ & $(2,653)$ & $(6,168)$ & $(9,670)$ & $(16,940)$ & $(10,084)$ & $(10,899)$ \\
\hline Observations & 516 & 493 & 512 & 489 & 423 & 478 & 468 \\
\hline Certified & 168 & 145 & 164 & 141 & 75 & 130 & 120 \\
\hline Control & 348 & 348 & 348 & 348 & 348 & 348 & 348 \\
\hline \multicolumn{8}{|c|}{ Source: Elaborated by the authors. } \\
\hline \multicolumn{8}{|c|}{ Note: ${ }^{\dagger}$ the caliper size is defined as a $1 / 4$ of the standard deviation of the propensity score } \\
\hline Rosenba & 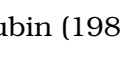 & ); optir & um band & vidth is ca & culated accor & ling to the $\mathrm{s}$ & rerman \\
\hline
\end{tabular}

The third additional test is the analysis of the certification's effect using the GDD method. This type of model is used when there is more than two years of assessment because it includes specific fixed effects regarding time and the municipalities (Wing et al., 2018). We use data ranging from 2001 to 2015, covering a greater number of pre-policy years (2001-2007). Moreover, we kept as the treatment group only the municipalities with at least one Green-Blue certification between 2008 and 2015. The control group is the municipalities that have not received certification for the entire period of analysis.

In the robustness check specification, the outcome variable is the number of hospitalizations due to airborne and waterborne diseases $\left(d a a_{w f}\right)$. Figure 5 shows the new dataset and the parallel trends between treated and control groups. 
Figure 5. Parallel trends between treated and control groups

(a) Warterborne and airborne diseases (without influenza)

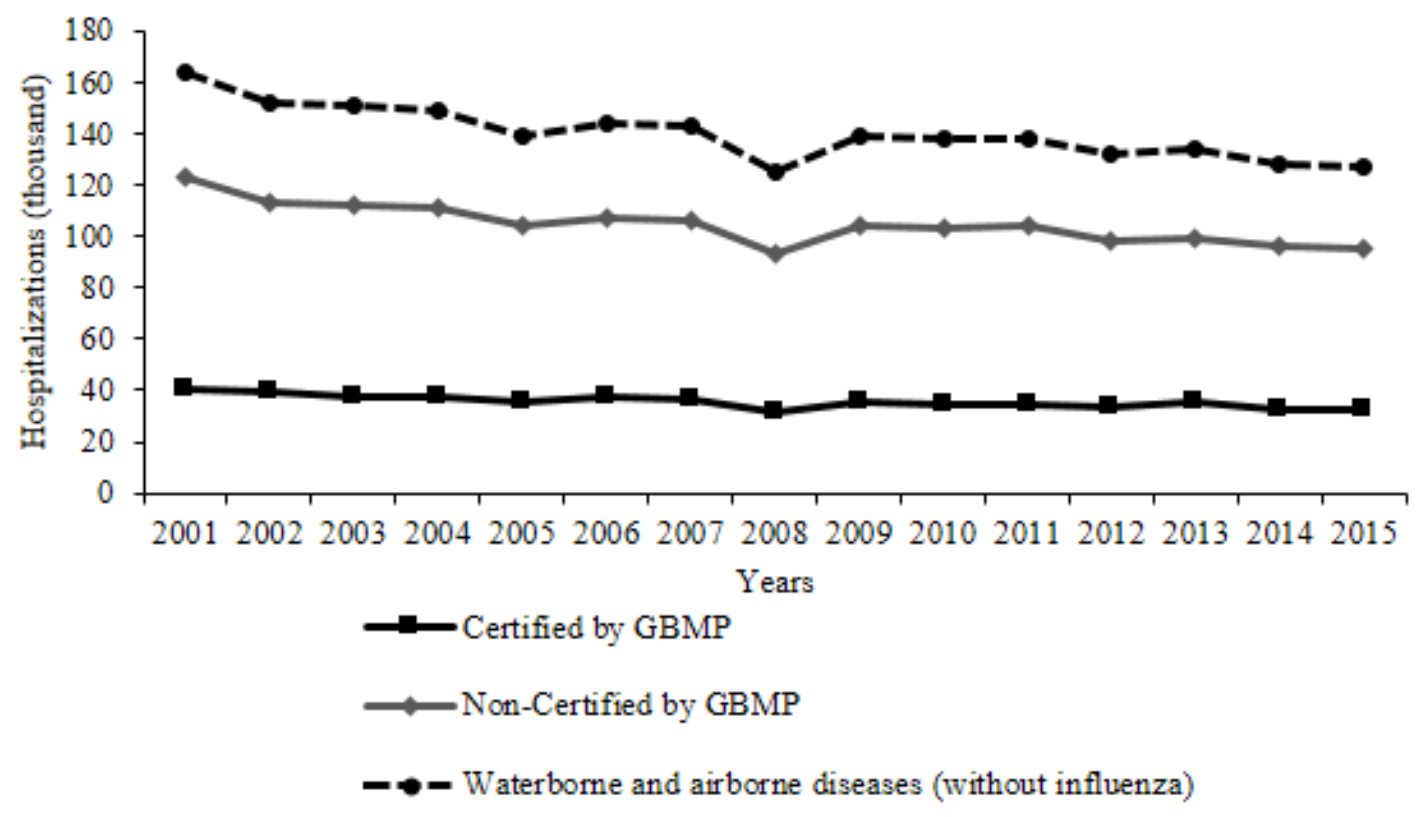

Source: Prepared by the authors with data from SAP (2016), DATASUS (2017) and CVE (2017).

The supplementary equation concerning the additional test is given by:

$$
d a a_{w f}=\beta_{0}+\beta_{1} \text { Treatment }_{i} \text { Time }_{i}+\beta_{2} £+a_{i}+\delta_{t}+\mu_{i}
$$

where $i=$ municipality; $t=$ year $(2001,2002, \ldots, 2015) ; a_{i}=$ fixed effects of each municipality; $\delta_{t}=$ fixed effect of each year; and $\mu_{i}=$ the error term. $\beta_{1}$ is an important coefficient, since it represents the effects of GBMP on the number of hospitalizations due to waterborne and airborne diseases - without influenza $\left(d a a_{w f}\right) . \beta_{2}$ represents the exposure time to treatment expressed as the dummy variable $£$, which $£=1$ if there is treatment, and $£=0$ otherwise. The results concerning the GBMP certification effects on $d a a_{w f}$ can be seen in Table 7.

The results suggest that there is no statistically significant effect of GBMP certification on the reduction of waterborne and airborne diseases cases (excluding influenza) in the treated municipalities, corroborating the results from the previous section. Furthermore, $\beta_{1}$, the coefficient of $£$, is not significant, indicating no effect of certification due to time exposure to GBMP. 
Table 7. GBMP certification effect

\begin{tabular}{lr}
\hline \hline Variable & Coefficient \\
\hline & \\
Outcome variable: waterborne and airborne diseases & \\
hospitalizations (excluding influenza) & -13.008 \\
& \\
Treatment Time $_{t}$ & $(18.239)$ \\
& -5.159 \\
$£_{i}$ & $(4.202)$ \\
& yes \\
\hline Time fixed effects & \\
\hline \hline Source: prepared by the authors & \\
Note: Asterisks denote statistical significance at $1 \%(* *)$, \\
$5 \%(* *)$, or $10 \%\left(^{*}\right)$ level; standard errors between parentheses.
\end{tabular}

\section{Conclusions}

This study evaluated the impact of GBMP certification on the number of cases of diseases regarding air and water quality between 2007 and 2015 in the municipalities of São Paulo State. The identification strategy used combined the methods of Propensity Score Matching and Difference-in-Differences. After the matching and tests related with the pairing procedure, the control and treated group were balanced. The results of DID-matching indicate that GBMP certification had no effect on the number of hospitalizations due to airborne and waterborne diseases.

Some potential causes for this result can be highlighted. The brief time of program implementation, the little publicity, and the need of better definition of benefits associated with participation in the program are the first reasons that we identify in our analysis. In addition, the lack of information on disease numbers, the Brazilian political dispute and non-release environmental data of all municipalities of state can contribute to non-significant GBMP certification results. Therefore, program improvement is suggested through a clearer system of benefits and more economically efficient, making it attractive for adhesion of local public management. In addition, a better focus of the program, with well-defined goals, can help the implementation, conduction, and its success.

As a first robustness check, we performed estimates considering as a control group only the municipalities that were not certified by GBMP from 2009 to 2015 and adopting as dependent variable the number of hospitalizations due to waterborne and airborne diseases (except influenza) between 2001 and 2015. The results corroborated the absence of effect of the GBMP certification. In addition, we proposed a second robustness check (placebo test) using hospitalizations due to assaults that occurred in the period from 2009 to 2015 as a result variable. The estimates showed the nonexistence of effect of the program certification in hospitalizations due to assaults, which validates our major results obtained. 
This paper presents three important limitations. First, our analysis is partial since evaluates the GBMP effects after the certification, excluding the need of improvement of the environmental quality to apply for the possible certification. Second, the Environmental Assessment Index used to rank the municipalities for the certification became stricter. First and second limitations contribute, both, to underestimate the post-certification effects of the program. Third, another important limitation of this paper consists of the short time of implementation of GBMP, since the improvement of water quality and air quality demands continued investments over several years. Thus, our findings did not exhaust the analysis of the effects of the Green-Blue Municipality certification and suggest future research for this topic considering a longer period of implementation of the program. Another avenue for future research is the evaluation of the program using discontinuous regression methodology, aiming to identifying further changes in the effect of the program.

\section{References}

Amaral, L. A. d., Nader Filho, A., Rossi Junior, O. D., Ferreira, F. L. A., and Barros, L. S. S. (2003). Água de consumo humano como fator de risco à saúde em propriedades rurais. Revista de Saúde Pública, 37:510-514.

Andrade, T. Y. I. and Talamoni, J. L. B. (2013). A educação ambiental nas escolas municipais de Brotas (SP): análise de concepções e ações no contexto do programa Município Verde Azul. Encontro de pesquisa em educação ambiental: questões epistemológicas contemporâneas: o debate modernidade/pós modernidade.

Angrist, J. D. and Pischke, J. S. (2009). Mostly harmless econometrics: An empiricist's companion. An empiricist's companion. Princeton: Princeton University Press.

Arima, E. Y., Barreto, P., Araújo, E., and Soares-Filho, B. (2014). Public policies can reduce tropical deforestation: Lessons and challenges from Brazil. Land use policy, 41:465-473.

Barbosa, C. R. (2014). Programa ambiental estratégico Município Verde Azul: desafios e dificuldades de um modelo de gestão pública compartilhada do meio ambiente. I Seminários Internacional de Pesquisa em Políticas Públicas e Desenvolvimento Social, Franca, SP, Brasil.

Braga, A., Pereira, L. A. A., Böhm, G. M., and Saldiva, P. (2001). Poluição atmosférica e saúde humana. Revista USP, 51(1):58-71.

Caliendo, M. and Kopeinig, S. (2008). Some practical guidance for the implementation of propensity score matching. Journal of Economic Surveys, 22(1):31-72.

Carneseca, E. C., Achcar, J. A., and Martinez, E. Z. (2012). Association between particulate matter air pollution and monthly inhalation and nebulization procedures in Ribeirão Preto, São Paulo State, Brazil. Cadernos de Saúde Pública, 28(1):15911598. 
CETESB (2010). Qualidade das águas superficiais no estado de São Paulo 2009. Companhia Ambiental do Estado de São Paulo.

CETESB (2020). Fecop - fundo estadual de prevenção e controle da poluição. Companhia Ambiental do Estado de São Paulo.

Chabé-Ferret, S. and Subervie, J. (2013). How much green for the buck? estimating additional and windfall effects of french agro-environmental schemes by didmatching. Journal of Environmental Economics and Management, 65(1):12-27.

Chagas, A. L., Azzoni, C. R., and Almeida, A. N. (2016). A spatial difference-indifferences analysis of the impact of sugarcane production on respiratory diseases. Regional Science and Urban Economics, 59:24-36.

Christovão, D. d. A., Iaria, S. T., and Candeias, J. A. N. (1967). Condições sanitárias das águas de irrigação de hortas do município de São Paulo: I. Determinação da intensidade de poluição fecal através NMP de coliformes e de E. coli. Revista de Saúde Pública, 1:3-11.

DATASUS (2017). Doenças e agravos de notificação. DATASUS - Departamento de Informática do Sus.

Duflo, E., Glennerster, R., and Kremer, M. (2007). Using randomization in development economics research: A toolkit. In Duflo, E., Glennerster, R., Kremer, M., Schultz, T. P., and Strauss, J., editors, Handbook of Development Economics, volume 4, pages 3895-3962. Elsevier, Amsterdam.

Freitas, C. U. d., Leon, A. P. d., Junger, W., and Gouveia, N. (2016). Poluição do ar e impactos na saúde em Vitória, Espírito Santo. Revista de Saúde Pública, 50(2):4865.

Gehrsitz, M. (2017). The effect of low emission zones on air pollution and infant health. Journal of Environmental Economics and Management, 83(5):121-144.

Giatti, L. L., Rocha, A. A., Santos, F. A. d., Bitencourt, S. C., and Pieroni, S. R. d. M. (2004). Condições de saneamento básico em Iporanga, Estado de São Paulo. Revista de Saúde Pública, 38(3):571-577.

Habermann, M., Souza, M., Prado, R., and Gouveia, N. (2014). Socioeconomic inequalities and exposure to traffic-related air pollution in the city of São Paulo, Brazil. Cadernos de Saúde Pública, 30(1):119-125.

Heinrich, C., Maffioli, A., and Vazquez, G. (2010). A primer for applying propensityscore matching. Technical Notes. Inter-American Development Bank.

Ho, D. E., Imai, K., King, G., and Stuart, E. A. (2007). Matching as nonparametric preprocessing for reducing model dependence in parametric causal inference. Political analysis, 15(3):199-236. 
IBGE (2017). Mapa dos estados brasileiros. Instituto Brasileiro de Geografia e Estatística.

Joly, M. (2017). Corruption: The shortcut to disaster. Sustainable Production and Consumption, 10(1):133-156.

Khandker, S. R., Koolwal, G. B., and Samad, H. A. (2009). Handbook on impact evaluation: quantitative methods and practices. World Bank Publications.

Lee, W.-S. (2013). Propensity score matching and variations on the balancing test. Empirical Economics, 44(1):47-80.

Leuven, E. and Sianesi, B. (2015). PSMATCH2: Stata module to perform full Mahalanobis and propensity score matching, common support graphing, and covariate imbalance testing. Statistical Software Components. Boston College Department of Economics.

Li, G., He, Q., Shao, S., and Cao, J. (2018). Environmental non-governmental organizations and urban environmental governance: Evidence from China. Journal of Environmental Management, 206(2): 1296-1307.

Lima, L. G. d. S. and Freitas, A. C. d. (2014). Estudo da qualidade da água de coariam através de análises físico-químicas e microbiológicas e correlação com doenças causadas por vias hídricas. IGAPÓ-Anais de Iniciação Científica.

Mazzoli-Rocha, F., Magalhaes, C. B., Malm, O., Saldiva, P. H. N., Zin, W. A., and Faffe, D. S. (2008). Comparative respiratory toxicity of particles produced by traffic and sugar cane burning. Environmental research, 108(1):35-41.

Moraes, G. I. and Serra, M. A. (2006). Gualidade de vida e involução metropolitana: Existe um ponto ótimo para a concentração urbana? Revista Econômica, 8(1):29-53.

Moreira Jr, O. (2010). O social e o ambiental nas cidades contemporâneas: embates, desafios e incertezas. Geografia, 19(1):87-100.

Nardocci, A. C., Freitas, C. U. d., Ponce de Leon, A. C. M., Junger, W. L., and Gouveia, N. d. C. (2013). Poluição do ar e doenças respiratórias e cardiovasculares: estudo de séries temporais em Cubatão, São Paulo, Brasil. Cadernos de Saúde Pública, 29:1867-1876.

Oliveira, B. F. A. d., Ignotti, E., and Hacon, S. S. (2013). A systematic review of the physical and chemical characteristics of pollutants from biomass burning and combustion of fossil fuels and health effects in Brazil. Cadernos de saude publica, 27:1678-1698.

Ravallion, M. (2007). Evaluating anti-poverty programs. In Duflo, E., Glennerster, R., Kremer, M., Schultz, T. P., and Strauss, J., editors, Handbook of Development Economics, volume 4, pages 3787-3846. Elsevier, Amsterdam. 
Rosenbaum, P. R. and Rubin, D. B. (1983). The central role of the propensity score in observational studies for causal effects. Biometrika, 70(1):41-55.

Salheb, G. J. M., Neto, H. A. P. P., Oliveira, I. M., Amaral Júnior, M. F., Souza Boettger, R. J. C., Souza Monteiro, V. C., and Superti, E. (2009). Políticas públicas e meio ambiente: reflexões preliminares. Planeta Amazônia: Revista Internacional de Direito Ambiental e Politicas Públicas, (1):5-26.

Santos, P. F. A., de Almeida, A. N., Lacerda, L. P. T., Silva, S. M., and Brito, R. A. (2016). Os Impactos do Programa Municípios Verdes (PMV) no Controle do Desmatamento da Amazônia: uma análise usando propensity score matching. Revista Economia Ensaios, 30(2):32-48.

Sianesi, B. (2004). An evaluation of the Swedish system of active labor market programs in the 1990s. Review of Economics and statistics, 86(1):133-155.

Silva, L. S. P. D. (2012). Controlo da qualidade da água de consumo humano no concelho da Povoação (São Miguel): diagnóstico e implicações para a saúde pública. Master's thesis, Programa de Pós-Graduação Ambiente, Saúde e Segurança. Universidade dos Açores.

Silva, R. d. C. A. d. and Araújo, T. M. d. (2003). Gualidade da água do manancial subterrâneo em áreas urbanas de Feira de Santana (BA). Ciência \& Saúde Coletiva, 8:1019-1028.

Smith, H. L. (1997). 6. matching with multiple controls to estimate treatment effects in observational studies. Sociological methodology, 27(1):325-353.

UNICA (2017). Base de dados: Unicadata. União da Indústria de Cana-de-Açúcar.

Wing, C., Simon, K., and Bello-Gomez, R. A. (2018). Designing difference in difference studies: best practices for public health policy research. Annual review of public health, 39.

Yanagi, Y., Assunção, J. V. d., and Barrozo, L. V. (2012). The impact of atmospheric particulate matter on cancer incidence and mortality in the city of São Paulo, Brazil. Cadernos de Saúde Pública, 28:1737-1748.

Zhao, Y., Ercan, T., and Tatari, O. (2016). Life cycle based multi-criteria optimization for optimal allocation of commercial delivery truck fleet in the United States. Sustainable Production and Consumption, 8:18-31.

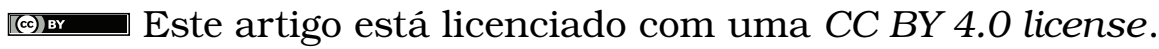




\section{Appendix A: Variables}

Table A.1. Weights of each directive of Green-Blue Municipality Program

\begin{tabular}{lc}
\hline Directives & Weights \\
\hline 1. Sewage Treatment & 1.2 \\
2. Water Management & 1.0 \\
3. Solid Waste & 1.2 \\
4. Sustainable City & 1.0 \\
5. Biodiversity & 1.0 \\
6. Urban Afforestation & 0.8 \\
7. Environmental Education & 1.0 \\
8. Air Quality & 0.8 \\
9. Environmental Structure & 1.0 \\
10. Environmental Council & 1.0 \\
\hline
\end{tabular}

Source: SMA (2016).

Table A.2. Selected diseases (continues)

\begin{tabular}{|c|c|}
\hline \multirow{2}{*}{\multicolumn{2}{|c|}{$\begin{array}{l}\text { Classification Description } \\
\text { Waterborne diseases }\end{array}$}} \\
\hline & eases \\
\hline \multicolumn{2}{|c|}{ Chapter I - Certain infectious and parasitic diseases (A00-B99) } \\
\hline A00-A09 & Intestinal infectious diseases \\
\hline AOO & Cholera \\
\hline A01.0 & Typhoid fever \\
\hline A05.1 & Botulism \\
\hline \multirow[t]{6}{*}{ A07.9 } & Protozoal intestinal disease, unspecified \\
\hline & Flagellate diarrhoea \\
\hline & Protozoal: \\
\hline & colitis \\
\hline & diarrhoea \\
\hline & dysentery \\
\hline A08.0 & Rotaviral enteritis \\
\hline \multirow[t]{15}{*}{ A09.0 } & Other and unspecified gastroenteritis and colitis of infectious origin \\
\hline & Catarrh, enteric or intestinal \\
\hline & Diarrhoea: \\
\hline & acute bloody \\
\hline & acute haemorrhagic \\
\hline & acute watery \\
\hline & dysenteric \\
\hline & epidemic \\
\hline & Infectious or septic \\
\hline & colitis \\
\hline & enteritis \\
\hline & gastroenteritis \\
\hline & NOS \\
\hline & haemorrhagic \\
\hline & Infectious (neonatal) diarrhoea NOS \\
\hline A20-A28 & Certain zoonotic bacterial diseases \\
\hline A27 & Leptospirosis \\
\hline B15-B19 & Viral hepatitis \\
\hline B15 & Acute hepatitis A \\
\hline B65-B83 & Helminthiases \\
\hline B65 & Schistosomiasis [bilharziasis] \\
\hline
\end{tabular}

Source: World Health Organization (2020) and Datasus (2017), classification available in:

a) https://icd.who.int/browse10/2019/en\#/X;

b) https://icd.who.int/browse10/2019/en\#/XX;

c) http://www2.datasus.gov.br/DATASUS/index.php?area=02. 
Table A.2. Selected diseases (end)

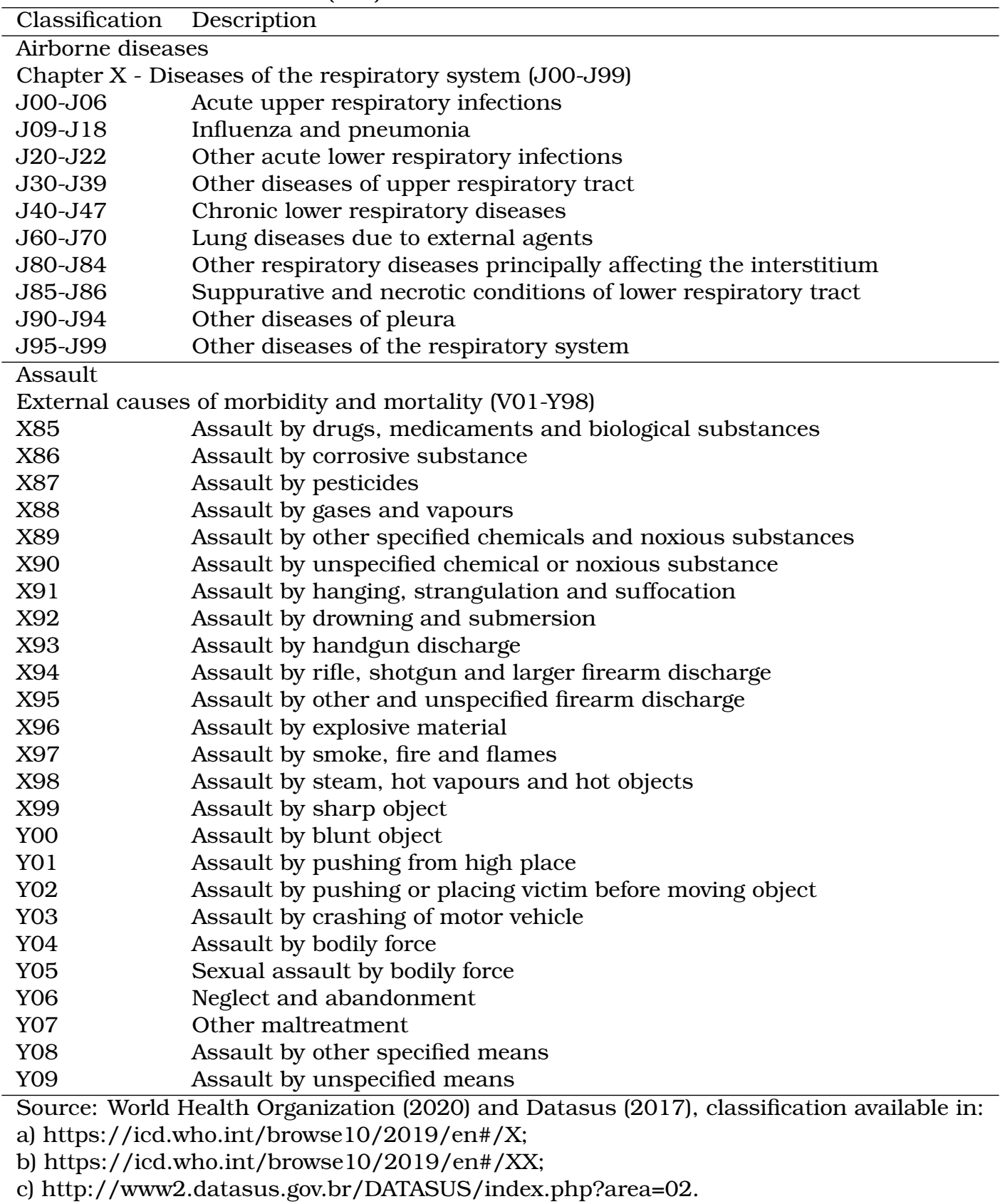




\section{Appendix B: Balancing statistics}

Table B.1. Balancing statistics between Certificated by GBMP and Non-Certificated by GBMP from 2009 to 2010 (data with influenza)

\begin{tabular}{|c|c|c|c|c|c|c|c|c|}
\hline \multirow[t]{2}{*}{ Variable } & \multicolumn{2}{|c|}{$\begin{array}{l}\text { Nearest neighbor } \\
\text { without caliper }\end{array}$} & \multicolumn{2}{|c|}{$\begin{array}{l}\text { Nearest neighbor } \\
\text { with caliper }^{\dagger}\end{array}$} & \multicolumn{2}{|c|}{ Kernel $^{€}$} & \multicolumn{2}{|c|}{$\begin{array}{l}\text { Matching } \\
\text { covariate }\end{array}$} \\
\hline & Bias (\%) & $\mathrm{p}$-value & Bias (\%) & $\mathrm{p}$-value & Bias (\%) & $\mathrm{p}$-value & Bias (\%) & p-value \\
\hline Year: 2009 & & & & & & & & \\
\hline ln_gdp & 0.80 & 0.94 & 2.70 & 0.79 & 2.40 & 0.81 & 10.00 & 0.34 \\
\hline hdi & 0.50 & 0.96 & 2.50 & 0.80 & 3.30 & 0.74 & 16.20 & 0.09 \\
\hline popurban & -2.90 & 0.78 & 1.00 & 0.92 & 0.70 & 0.94 & 5.10 & 0.62 \\
\hline c_dae & 2.30 & 0.80 & -0.50 & 0.96 & -1.30 & 0.90 & 4.50 & 0.65 \\
\hline c_ch & 0.00 & 1.00 & -2.40 & 0.83 & -3.60 & 0.74 & 0.00 & 1.00 \\
\hline c_saae & 0.00 & 1.00 & -0.60 & 0.95 & -0.90 & 0.93 & 0.00 & 1.00 \\
\hline c_sae & -3.50 & 0.79 & 0.50 & 0.97 & 0.60 & 0.96 & 0.00 & 1.00 \\
\hline c_sabesp & 5.00 & 0.65 & 2.70 & 0.80 & 4.20 & 0.70 & -3.60 & 0.74 \\
\hline part_ind_av & 6.80 & 0.49 & 1.10 & 0.91 & 0.00 & 1.00 & 2.60 & 0.80 \\
\hline part_agro_av & -0.40 & 0.97 & -3.00 & 0.79 & -1.40 & 0.90 & -3.20 & 0.77 \\
\hline aut & -3.00 & 0.74 & 0.70 & 0.94 & 0.50 & 0.95 & 19.50 & 0.02 \\
\hline bus & -3.10 & 0.72 & 0.20 & 0.98 & 0.00 & 1.00 & 16.90 & 0.03 \\
\hline trucks & -4.00 & 0.65 & 0.60 & 0.95 & 0.40 & 0.96 & 18.60 & 0.03 \\
\hline motorcycles & -1.80 & 0.84 & 2.30 & 0.79 & 2.30 & 0.78 & 19.90 & 0.05 \\
\hline micro-buses & -3.30 & 0.70 & 1.00 & 0.91 & 0.80 & 0.92 & 20.40 & 0.03 \\
\hline urb & -2.50 & 0.79 & 0.70 & 0.94 & 1.00 & 0.92 & 1.50 & 0.87 \\
\hline Year: 2010 & & & & & & & & \\
\hline ln_gdp & 5.00 & 0.62 & -0.50 & 0.96 & 0.80 & 0.94 & 11.20 & 0.32 \\
\hline hdi & 4.90 & 0.65 & -1.30 & 0.91 & -0.50 & 0.96 & 11.70 & 0.27 \\
\hline popurban & 0.50 & 0.66 & -0.30 & 0.79 & -0.10 & 0.91 & 13.70 & 0.24 \\
\hline c_dae & 0.00 & 1.00 & -2.10 & 0.86 & -3.00 & 0.80 & -2.60 & 0.81 \\
\hline c_ch & -5.70 & 0.63 & -2.40 & 0.84 & -3.30 & 0.78 & 0.00 & 1.00 \\
\hline c_saae & 2.90 & 0.80 & 1.30 & 0.91 & 0.00 & 1.00 & 0.00 & 1.00 \\
\hline c_sae & 3.70 & 0.79 & 2.80 & 0.84 & 3.50 & 0.81 & 0.00 & 1.00 \\
\hline c_sabesp & -1.50 & 0.90 & 5.80 & 0.63 & 4.80 & 0.69 & 0.00 & 1.00 \\
\hline part_ind_av & 4.60 & 0.67 & 2.00 & 0.86 & 0.50 & 0.97 & -2.40 & 0.82 \\
\hline part_agro_av & -1.50 & 0.90 & 0.60 & 0.96 & 0.00 & 1.00 & 0.60 & 0.96 \\
\hline aut & 0.50 & 0.59 & -0.30 & 0.81 & -0.10 & 0.91 & 13.90 & 0.24 \\
\hline bus & 0.50 & 0.53 & -0.50 & 0.64 & -0.30 & 0.80 & 13.00 & 0.27 \\
\hline trucks & 1.10 & 0.48 & -0.30 & 0.87 & 0.00 & 1.00 & 14.80 & 0.21 \\
\hline motorcycles & 0.90 & 0.66 & -1.50 & 0.55 & -0.50 & 0.82 & 15.80 & 0.18 \\
\hline micro-buses & 0.40 & 0.63 & -0.30 & 0.77 & -0.10 & 0.91 & 13.90 & 0.24 \\
\hline urb & -4.00 & 0.67 & -0.60 & 0.96 & 0.10 & 0.99 & -1.60 & 0.87 \\
\hline
\end{tabular}

Source: Elaborated by the authors based on the results. 
Table B.2. Balancing statistics between Certificated by GBMP and Non-Certificated by GBMP from 2011 to 2012 (data with influenza)

\begin{tabular}{|c|c|c|c|c|c|c|c|c|}
\hline \multirow[t]{2}{*}{ Variable } & \multicolumn{2}{|c|}{$\begin{array}{l}\text { Nearest neighbor } \\
\text { without caliper }\end{array}$} & \multicolumn{2}{|c|}{$\begin{array}{l}\text { Nearest neighbor } \\
\text { with caliper }^{\dagger}\end{array}$} & \multicolumn{2}{|c|}{ Kernel $^{€}$} & \multicolumn{2}{|c|}{$\begin{array}{l}\text { Matching } \\
\text { covariate }\end{array}$} \\
\hline & Bias (\%) & p-value & Bias (\%) & p-value & Bias (\%) & p-value & Bias (\%) & $\mathrm{p}$-value \\
\hline \multicolumn{9}{|l|}{ Year: 2011} \\
\hline ln_gdp & 10.60 & 0.29 & 8.90 & 0.38 & 7.40 & 0.47 & 17.30 & 0.10 \\
\hline hdi & 0.60 & 0.96 & 7.10 & 0.51 & 6.50 & 0.55 & 16.00 & 0.14 \\
\hline popurban & 0.40 & 0.76 & 0.70 & 0.56 & 0.50 & 0.70 & 13.70 & 0.21 \\
\hline c_dae & -9.80 & 0.40 & -0.30 & 0.98 & -1.60 & 0.88 & 0.00 & 1.00 \\
\hline c_ch & 0.00 & 1.00 & -0.20 & 0.99 & -0.60 & 0.96 & 0.00 & 1.00 \\
\hline c_saae & 0.00 & 1.00 & 0.70 & 0.95 & -0.80 & 0.94 & 0.00 & 1.00 \\
\hline c_sae & 6.20 & 0.63 & 0.70 & 0.96 & 2.20 & 0.87 & 0.00 & 1.00 \\
\hline c_sabesp & 2.60 & 0.82 & 0.60 & 0.96 & 1.50 & 0.89 & -1.20 & 0.91 \\
\hline part_ind_av & 5.10 & 0.62 & 6.00 & 0.57 & 4.10 & 0.69 & 2.20 & 0.82 \\
\hline part_agro_av & -9.20 & 0.44 & -8.60 & 0.47 & -6.10 & 0.61 & -0.60 & 0.95 \\
\hline aut & 0.30 & 0.84 & 0.60 & 0.61 & 0.40 & 0.74 & 14.00 & 0.20 \\
\hline bus & 0.30 & 0.84 & 0.50 & 0.70 & 0.20 & 0.85 & 13.00 & 0.24 \\
\hline trucks & 0.60 & 0.78 & 1.20 & 0.58 & 0.80 & 0.69 & 15.60 & 0.15 \\
\hline motorcycles & 1.30 & 0.57 & 1.60 & 0.50 & 1.20 & 0.62 & 16.30 & 0.14 \\
\hline micro-buses & 0.30 & 0.78 & 0.60 & 0.58 & 0.40 & 0.71 & 14.10 & 0.20 \\
\hline urb & 3.70 & 0.70 & 4.00 & 0.68 & 3.50 & 0.72 & 2.40 & 0.79 \\
\hline \multicolumn{9}{|l|}{ Year: 2012} \\
\hline ln_gdp & 6.00 & 0.60 & -5.60 & 0.64 & -1.90 & 0.88 & 9.60 & 0.41 \\
\hline hdi & 8.00 & 0.51 & -2.80 & 0.82 & 0.20 & 0.99 & 7.80 & 0.50 \\
\hline popurban & 1.70 & 0.21 & -0.10 & 0.93 & 0.40 & 0.80 & 13.80 & 0.24 \\
\hline c_dae & 5.80 & 0.61 & 2.90 & 0.81 & 3.30 & 0.78 & -2.80 & 0.81 \\
\hline c_ch & 9.90 & 0.37 & -0.80 & 0.94 & -1.50 & 0.90 & 0.00 & 1.00 \\
\hline c_saae & 6.10 & 0.59 & 2.30 & 0.85 & 2.40 & 0.84 & 0.00 & 1.00 \\
\hline c_sae & 0.00 & 1.00 & -2.80 & 0.85 & -2.50 & 0.87 & 0.00 & 1.00 \\
\hline c_sabesp & -19.00 & 0.11 & -4.80 & 0.70 & -7.50 & 0.53 & 1.40 & 0.91 \\
\hline part_ind_av & 3.70 & 0.74 & 1.90 & 0.86 & 4.40 & 0.69 & -4.90 & 0.65 \\
\hline part_agro_av & -11.60 & 0.36 & -1.30 & 0.92 & -2.30 & 0.85 & -1.60 & 0.89 \\
\hline aut & 1.80 & 0.15 & 0.30 & 0.79 & 0.80 & 0.53 & 16.00 & 0.18 \\
\hline bus & 1.10 & 0.32 & -1.10 & 0.40 & -0.70 & 0.63 & 13.90 & 0.24 \\
\hline trucks & 3.10 & 0.18 & -1.10 & 0.66 & -0.20 & 0.95 & 18.30 & 0.12 \\
\hline motorcycles & 3.00 & 0.25 & 2.00 & 0.42 & 2.40 & 0.34 & 18.40 & 0.12 \\
\hline micro-buses & 1.90 & 0.14 & -0.20 & 0.91 & 0.40 & 0.79 & 16.30 & 0.17 \\
\hline urb & -4.10 & 0.68 & -2.70 & 0.80 & -2.00 & 0.85 & 1.00 & 0.92 \\
\hline
\end{tabular}

Source: Elaborated by the authors based on the results. 
Table B.3. Balancing statistics between Certificated by GBMP and Non-Certificated by GBMP from 2013 to 2014 (data with influenza)

\begin{tabular}{|c|c|c|c|c|c|c|c|c|}
\hline \multirow[t]{2}{*}{ Variable } & \multicolumn{2}{|c|}{$\begin{array}{l}\text { Nearest neighbor } \\
\text { without caliper }\end{array}$} & \multicolumn{2}{|c|}{$\begin{array}{l}\text { Nearest neighbor } \\
\text { with caliper }^{\dagger}\end{array}$} & \multicolumn{2}{|c|}{ Kernel $^{€}$} & \multicolumn{2}{|c|}{$\begin{array}{l}\text { Matching } \\
\text { covariate }\end{array}$} \\
\hline & Bias (\%) & $\mathrm{p}$-value & Bias (\%) & $\mathrm{p}$-value & Bias (\%) & p-value & Bias (\%) & p-value \\
\hline \multicolumn{9}{|l|}{ Year: 2013} \\
\hline ln_gdp & 8.70 & 0.61 & -8.90 & 0.60 & -8.50 & 0.61 & 16.40 & 0.34 \\
\hline hdi & 9.60 & 0.54 & 3.20 & 0.83 & 3.20 & 0.84 & 20.50 & 0.16 \\
\hline popurban & -1.70 & 0.89 & -6.90 & 0.55 & -7.00 & 0.55 & 18.70 & 0.24 \\
\hline c_dae & -5.30 & 0.77 & -2.30 & 0.89 & 0.50 & 0.98 & 0.00 & 1.00 \\
\hline c_ch & 3.90 & 0.81 & 2.40 & 0.88 & 2.70 & 0.86 & 0.00 & 1.00 \\
\hline c_saae & 0.00 & 1.00 & 12.00 & 0.49 & 12.30 & 0.47 & 0.00 & 1.00 \\
\hline c_sae & -8.00 & 0.70 & 4.10 & 0.83 & 3.60 & 0.85 & 0.00 & 1.00 \\
\hline c_sabesp & -2.80 & 0.87 & 8.30 & 0.63 & 8.10 & 0.63 & 0.00 & 1.00 \\
\hline part_ind_av & 15.50 & 0.35 & -4.30 & 0.79 & -1.40 & 0.93 & 1.60 & 0.92 \\
\hline part_agro_av & -15.80 & 0.40 & 11.00 & 0.53 & 10.00 & 0.57 & -0.60 & 0.97 \\
\hline aut & -1.80 & 0.88 & -5.50 & 0.62 & -5.50 & 0.62 & 22.50 & 0.17 \\
\hline bus & -5.60 & 0.66 & -6.80 & 0.50 & -7.60 & 0.45 & 18.40 & 0.25 \\
\hline trucks & -1.90 & 0.89 & -6.00 & 0.60 & -6.30 & 0.59 & 24.00 & 0.12 \\
\hline motorcycles & 1.10 & 0.94 & -20.50 & 0.20 & -20.50 & 0.20 & 24.60 & 0.16 \\
\hline micro-buses & -1.40 & 0.90 & -5.60 & 0.60 & -5.90 & 0.59 & 24.70 & 0.13 \\
\hline urb & 4.60 & 0.74 & 0.10 & 0.99 & 0.70 & 0.96 & 17.40 & 0.22 \\
\hline \multicolumn{9}{|l|}{ Year: 2014} \\
\hline ln_gdp & 13.10 & 0.27 & 5.00 & 0.68 & 6.30 & 0.60 & 13.10 & 0.30 \\
\hline hdi & 1.00 & 0.93 & 3.10 & 0.78 & 3.90 & 0.73 & 17.50 & 0.12 \\
\hline popurban & 9.70 & 0.15 & 1.50 & 0.83 & 4.20 & 0.59 & 20.30 & 0.08 \\
\hline c_dae & 6.30 & 0.63 & 5.10 & 0.70 & 2.50 & 0.85 & 0.00 & 1.00 \\
\hline c_ch & 0.00 & 1.00 & -2.20 & 0.87 & -2.50 & 0.84 & 0.00 & 1.00 \\
\hline c_saae & 3.20 & 0.80 & 1.60 & 0.90 & 3.50 & 0.78 & 0.00 & 1.00 \\
\hline c_sae & 0.00 & 1.00 & 1.60 & 0.91 & 1.00 & 0.95 & 0.00 & 1.00 \\
\hline c_sabesp & -3.30 & 0.80 & -2.10 & 0.87 & -0.10 & 0.99 & -6.20 & 0.62 \\
\hline part_ind_av & -0.70 & 0.96 & 6.80 & 0.58 & 5.80 & 0.63 & 5.20 & 0.65 \\
\hline part_agro_av & -4.70 & 0.70 & -1.10 & 0.93 & -0.90 & 0.94 & -5.10 & 0.65 \\
\hline aut & 9.70 & 0.14 & 1.80 & 0.79 & 4.50 & 0.55 & 24.70 & 0.04 \\
\hline bus & 10.20 & 0.07 & 0.20 & 0.98 & 2.70 & 0.71 & 17.80 & 0.12 \\
\hline trucks & 11.60 & 0.10 & 3.10 & 0.70 & 5.40 & 0.52 & 22.80 & 0.05 \\
\hline motorcycles & 10.50 & 0.23 & 0.00 & 1.00 & 2.70 & 0.78 & 29.10 & 0.02 \\
\hline micro-buses & 10.10 & 0.15 & 2.40 & 0.73 & 5.00 & 0.52 & 26.90 & 0.03 \\
\hline urb & 4.60 & 0.66 & -1.20 & 0.90 & -0.50 & 0.96 & 2.50 & 0.80 \\
\hline
\end{tabular}

Source: Elaborated by the authors based on the results. 
Table B.4. Balancing statistics between Certificated by GBMP and Non-Certificated by GBMP of 2015 (data with influenza)

\begin{tabular}{|c|c|c|c|c|c|c|c|c|}
\hline \multirow[t]{2}{*}{ Variable } & \multicolumn{2}{|c|}{$\begin{array}{l}\text { Nearest neighbor } \\
\text { without caliper }\end{array}$} & \multicolumn{2}{|c|}{$\begin{array}{l}\text { Nearest neighbor } \\
\text { with caliper }\end{array}$} & \multicolumn{2}{|c|}{ Kernel $^{€}$} & \multicolumn{2}{|c|}{$\begin{array}{l}\text { Matching } \\
\text { covariate }\end{array}$} \\
\hline & Bias (\%) & p-value & Bias (\%) & p-value & Bias (\%) & p-value & Bias (\%) & $\mathrm{p}$-value \\
\hline \multicolumn{9}{|l|}{ Year: 2015} \\
\hline ln_gdp & 7.30 & 0.58 & 1.40 & 0.91 & 3.20 & 0.80 & 15.30 & 0.24 \\
\hline hdi & 2.50 & 0.83 & 2.00 & 0.86 & 3.00 & 0.80 & 22.00 & 0.05 \\
\hline popurban & -2.50 & 0.80 & 0.60 & 0.94 & 1.00 & 0.90 & 23.80 & 0.04 \\
\hline c_dae & -3.90 & 0.78 & 4.70 & 0.70 & 2.80 & 0.82 & 0.00 & 1.00 \\
\hline c_ch & 4.80 & 0.70 & -5.60 & 0.67 & -5.10 & 0.70 & 0.00 & 1.00 \\
\hline c_saae & -6.80 & 0.66 & 4.30 & 0.76 & 4.10 & 0.77 & 0.00 & 1.00 \\
\hline c_sae & 6.60 & 0.56 & 1.40 & 0.92 & 0.60 & 0.96 & 0.00 & 1.00 \\
\hline c_sabesp & 3.60 & 0.79 & 2.80 & 0.83 & 1.90 & 0.89 & -5.00 & 0.70 \\
\hline part_ind_av & 8.60 & 0.49 & 7.50 & 0.55 & 6.00 & 0.64 & 7.00 & 0.55 \\
\hline part_agro_av & 1.50 & 0.90 & 3.10 & 0.81 & 1.40 & 0.91 & -3.10 & 0.79 \\
\hline aut & -2.50 & 0.80 & 1.40 & 0.86 & 1.70 & 0.83 & 27.50 & 0.03 \\
\hline bus & -5.20 & 0.61 & -1.00 & 0.90 & 0.40 & 0.97 & 19.30 & 0.11 \\
\hline trucks & -3.40 & 0.73 & 0.40 & 0.96 & 1.40 & 0.87 & 25.60 & 0.03 \\
\hline motorcycles & 1.70 & 0.86 & -2.30 & 0.82 & 0.10 & 0.99 & 30.40 & 0.02 \\
\hline micro-buses & -2.40 & 0.80 & 1.30 & 0.87 & 2.00 & 0.81 & 29.30 & 0.02 \\
\hline urb & -0.20 & 0.99 & -1.60 & 0.88 & -0.80 & 0.95 & 4.10 & 0.69 \\
\hline
\end{tabular}

Source: Elaborated by the authors based on the results. 
Table B.5. Balancing statistics between Certificated by GBMP and Non-Certificated by GBMP from 2009 to 2010 (data without influenza)

\begin{tabular}{|c|c|c|c|c|c|c|c|c|}
\hline \multirow[t]{2}{*}{ Variable } & \multicolumn{2}{|c|}{$\begin{array}{l}\text { Nearest neighbor } \\
\text { without caliper }\end{array}$} & \multicolumn{2}{|c|}{$\begin{array}{l}\text { Nearest neighbor } \\
\text { with caliper }^{\dagger}\end{array}$} & \multicolumn{2}{|c|}{ Kernel $^{€}$} & \multicolumn{2}{|c|}{$\begin{array}{l}\text { Matching } \\
\text { covariate }\end{array}$} \\
\hline & Bias (\%) & p-value & Bias (\%) & p-value & Bias (\%) & p-value & Bias (\%) & $\mathrm{p}$-value \\
\hline Year: 2009 & & & & & & & & \\
\hline ln_gdp & 0.80 & 0.94 & 2.70 & 0.79 & 2.40 & 0.81 & 10.00 & 0.34 \\
\hline hdi & 0.50 & 0.96 & 2.50 & 0.80 & 3.30 & 0.74 & 16.20 & 0.09 \\
\hline popurban & -2.90 & 0.78 & 1.00 & 0.92 & 0.70 & 0.94 & 5.10 & 0.62 \\
\hline c_dae & 2.30 & 0.80 & -0.50 & 0.96 & -1.30 & 0.90 & 4.50 & 0.65 \\
\hline c_ch & 0.00 & 1.00 & -2.40 & 0.83 & -3.60 & 0.74 & 0.00 & 1.00 \\
\hline c_saae & 0.00 & 1.00 & -0.60 & 0.95 & -0.90 & 0.93 & 0.00 & 1.00 \\
\hline c_sae & -3.50 & 0.79 & 0.50 & 0.97 & 0.60 & 0.96 & 0.00 & 1.00 \\
\hline c_sabesp & 5.00 & 0.65 & 2.70 & 0.80 & 4.20 & 0.70 & -3.60 & 0.74 \\
\hline part_ind_av & 6.80 & 0.49 & 1.10 & 0.91 & 0.00 & 1.00 & 2.60 & 0.80 \\
\hline part_agro_av & -0.40 & 0.97 & -3.00 & 0.79 & -1.40 & 0.90 & -3.20 & 0.77 \\
\hline aut & -3.00 & 0.74 & 0.70 & 0.94 & 0.50 & 0.95 & 19.50 & 0.02 \\
\hline bus & -3.10 & 0.72 & 0.20 & 0.98 & 0.00 & 1.00 & 16.90 & 0.03 \\
\hline trucks & -4.00 & 0.65 & 0.60 & 0.95 & 0.40 & 0.96 & 18.60 & 0.03 \\
\hline motorcycles & -1.80 & 0.84 & 2.30 & 0.79 & 2.30 & 0.78 & 19.90 & 0.05 \\
\hline micro-buses & -3.30 & 0.70 & 1.00 & 0.91 & 0.80 & 0.92 & 20.40 & 0.03 \\
\hline urb & -2.50 & 0.79 & 0.70 & 0.94 & 1.00 & 0.92 & 1.50 & 0.87 \\
\hline Year: 2010 & & & & & & & & \\
\hline ln_gdp & 5.00 & 0.62 & -0.50 & 0.96 & 0.80 & 0.94 & 11.20 & 0.32 \\
\hline hdi & 4.90 & 0.65 & -1.30 & 0.91 & -0.50 & 0.96 & 11.70 & 0.27 \\
\hline popurban & 0.50 & 0.66 & -0.30 & 0.79 & -0.10 & 0.91 & 13.70 & 0.24 \\
\hline c_dae & 0.00 & 1.00 & -2.10 & 0.86 & -3.00 & 0.80 & -2.60 & 0.81 \\
\hline c_ch & -5.70 & 0.63 & -2.40 & 0.84 & -3.30 & 0.78 & 0.00 & 1.00 \\
\hline c_saae & 2.90 & 0.80 & 1.30 & 0.91 & 0.00 & 1.00 & 0.00 & 1.00 \\
\hline c_sae & 3.70 & 0.79 & 2.80 & 0.84 & 3.50 & 0.81 & 0.00 & 1.00 \\
\hline c_sabesp & -1.50 & 0.90 & 5.80 & 0.63 & 4.80 & 0.69 & 0.00 & 1.00 \\
\hline part_ind_av & 4.60 & 0.67 & 2.00 & 0.86 & 0.50 & 0.97 & -2.40 & 0.82 \\
\hline part_agro_av & -1.50 & 0.90 & 0.60 & 0.96 & 0.00 & 1.00 & 0.60 & 0.96 \\
\hline aut & 0.50 & 0.59 & -0.30 & 0.81 & -0.10 & 0.91 & 13.90 & 0.24 \\
\hline bus & 0.50 & 0.53 & -0.50 & 0.64 & -0.30 & 0.80 & 13.00 & 0.27 \\
\hline trucks & 1.10 & 0.48 & -0.30 & 0.87 & 0.00 & 1.00 & 14.80 & 0.21 \\
\hline motorcycles & 0.90 & 0.66 & -1.50 & 0.55 & -0.50 & 0.82 & 15.80 & 0.18 \\
\hline micro-buses & 0.40 & 0.63 & -0.30 & 0.77 & -0.10 & 0.91 & 13.90 & 0.24 \\
\hline
\end{tabular}

Source: Elaborated by the authors based on the results. 
Table B.6. Balancing statistics between Certificated by GBMP and Non-Certificated by GBMP from 2011 to 2012 (data without influenza)

\begin{tabular}{|c|c|c|c|c|c|c|c|c|}
\hline \multirow[t]{2}{*}{ Variable } & \multicolumn{2}{|c|}{$\begin{array}{l}\text { Nearest neighbor } \\
\text { without caliper }\end{array}$} & \multicolumn{2}{|c|}{$\begin{array}{l}\text { Nearest neighbor } \\
\text { with caliper }^{\dagger}\end{array}$} & \multicolumn{2}{|c|}{ Kernel $^{€}$} & \multicolumn{2}{|c|}{$\begin{array}{l}\text { Matching } \\
\text { covariate }\end{array}$} \\
\hline & Bias (\%) & p-value & Bias (\%) & p-value & Bias (\%) & p-value & Bias (\%) & $\mathrm{p}$-value \\
\hline \multicolumn{9}{|l|}{ Year: 2011} \\
\hline ln_gdp & 10.60 & 0.29 & 8.90 & 0.38 & 7.40 & 0.47 & 17.30 & 0.10 \\
\hline hdi & 0.60 & 0.96 & 7.10 & 0.51 & 6.50 & 0.55 & 16.00 & 0.14 \\
\hline popurban & 0.40 & 0.76 & 0.70 & 0.56 & 0.50 & 0.70 & 13.70 & 0.21 \\
\hline c_dae & -9.80 & 0.40 & -0.30 & 0.98 & -1.60 & 0.88 & 0.00 & 1.00 \\
\hline c_ch & 0.00 & 1.00 & -0.20 & 0.99 & -0.60 & 0.96 & 0.00 & 1.00 \\
\hline c_saae & 0.00 & 1.00 & 0.70 & 0.95 & -0.80 & 0.94 & 0.00 & 1.00 \\
\hline c_sae & 6.20 & 0.63 & 0.70 & 0.96 & 2.20 & 0.87 & 0.00 & 1.00 \\
\hline c_sabesp & 2.60 & 0.82 & 0.60 & 0.96 & 1.50 & 0.89 & -1.20 & 0.91 \\
\hline part_ind_av & 5.10 & 0.62 & 6.00 & 0.57 & 4.10 & 0.69 & 2.20 & 0.82 \\
\hline part_agro_av & -9.20 & 0.44 & -8.60 & 0.47 & -6.10 & 0.61 & -0.60 & 0.95 \\
\hline aut & 0.30 & 0.84 & 0.60 & 0.61 & 0.40 & 0.74 & 14.00 & 0.20 \\
\hline bus & 0.30 & 0.84 & 0.50 & 0.70 & 0.20 & 0.85 & 13.00 & 0.24 \\
\hline trucks & 0.60 & 0.78 & 1.20 & 0.58 & 0.80 & 0.69 & 15.60 & 0.15 \\
\hline motorcycles & 1.30 & 0.57 & 1.60 & 0.50 & 1.20 & 0.62 & 16.30 & 0.14 \\
\hline micro-buses & 0.30 & 0.78 & 0.60 & 0.58 & 0.40 & 0.71 & 14.10 & 0.20 \\
\hline urb & 3.70 & 0.70 & 4.00 & 0.68 & 3.50 & 0.72 & 2.40 & 0.79 \\
\hline \multicolumn{9}{|l|}{ Year: 2012} \\
\hline ln_gdp & 6.00 & 0.60 & -5.60 & 0.64 & -1.90 & 0.88 & 9.60 & 0.41 \\
\hline hdi & 8.00 & 0.51 & -2.80 & 0.82 & 0.20 & 0.99 & 7.80 & 0.50 \\
\hline popurban & 1.70 & 0.21 & -0.10 & 0.93 & 0.40 & 0.80 & 13.80 & 0.24 \\
\hline c_dae & 5.80 & 0.61 & 2.90 & 0.81 & 3.30 & 0.78 & -2.80 & 0.81 \\
\hline c_ch & 9.90 & 0.37 & -0.80 & 0.94 & -1.50 & 0.90 & 0.00 & 1.00 \\
\hline c_saae & 6.10 & 0.59 & 2.30 & 0.85 & 2.40 & 0.84 & 0.00 & 1.00 \\
\hline c_sae & 0.00 & 1.00 & -2.80 & 0.85 & -2.50 & 0.87 & 0.00 & 1.00 \\
\hline c_sabesp & -19.00 & 0.11 & -4.80 & 0.70 & -7.50 & 0.53 & 1.40 & 0.91 \\
\hline part_ind_av & 3.70 & 0.74 & 1.90 & 0.86 & 4.40 & 0.69 & -4.90 & 0.65 \\
\hline part_agro_av & -11.60 & 0.36 & -1.30 & 0.92 & -2.30 & 0.85 & -1.60 & 0.89 \\
\hline aut & 1.80 & 0.15 & 0.30 & 0.79 & 0.80 & 0.53 & 16.00 & 0.18 \\
\hline bus & 1.10 & 0.32 & -1.10 & 0.40 & -0.70 & 0.63 & 13.90 & 0.24 \\
\hline trucks & 3.10 & 0.18 & -1.10 & 0.66 & -0.20 & 0.95 & 18.30 & 0.12 \\
\hline motorcycles & 3.00 & 0.25 & 2.00 & 0.42 & 2.40 & 0.34 & 18.40 & 0.12 \\
\hline micro-buses & 1.90 & 0.14 & -0.20 & 0.91 & 0.40 & 0.79 & 16.30 & 0.17 \\
\hline urb & -4.10 & 0.68 & -2.70 & 0.80 & -2.00 & 0.85 & 1.00 & 0.92 \\
\hline
\end{tabular}

Source: Elaborated by the authors based on the results. 
Table B.7. Balancing statistics between Certificated by GBMP and Non-Certificated by GBMP from 2013 to 2014 (data without influenza)

\begin{tabular}{|c|c|c|c|c|c|c|c|c|}
\hline \multirow[t]{2}{*}{ Variable } & \multicolumn{2}{|c|}{$\begin{array}{l}\text { Nearest neighbor } \\
\text { without caliper }\end{array}$} & \multicolumn{2}{|c|}{$\begin{array}{l}\text { Nearest neighbor } \\
\text { with caliper }^{\dagger}\end{array}$} & \multicolumn{2}{|c|}{ Kernel $^{€}$} & \multicolumn{2}{|c|}{$\begin{array}{l}\text { Matching } \\
\text { covariate }\end{array}$} \\
\hline & Bias (\%) & p-value & Bias (\%) & p-value & Bias (\%) & $\mathrm{p}$-value & Bias (\%) & $\mathrm{p}$-value \\
\hline \multicolumn{9}{|l|}{ Year: 2013} \\
\hline ln_gdp & 8.70 & 0.61 & -8.90 & 0.60 & -8.50 & 0.61 & 16.40 & 0.34 \\
\hline hdi & 9.60 & 0.54 & 3.20 & 0.83 & 3.20 & 0.84 & 20.50 & 0.16 \\
\hline popurban & -1.70 & 0.89 & -6.90 & 0.55 & -7.00 & 0.55 & 18.70 & 0.24 \\
\hline c_dae & -5.30 & 0.77 & -2.30 & 0.89 & 0.50 & 0.98 & 0.00 & 1.00 \\
\hline c_ch & 3.90 & 0.81 & 2.40 & 0.88 & 2.70 & 0.86 & 0.00 & 1.00 \\
\hline c_saae & 0.00 & 1.00 & 12.00 & 0.49 & 12.30 & 0.47 & 0.00 & 1.00 \\
\hline c_sae & -8.00 & 0.70 & 4.10 & 0.83 & 3.60 & 0.85 & 0.00 & 1.00 \\
\hline c_sabesp & -2.80 & 0.87 & 8.30 & 0.63 & 8.10 & 0.63 & 0.00 & 1.00 \\
\hline part_ind_av & 15.50 & 0.35 & -4.30 & 0.79 & -1.40 & 0.93 & 1.60 & 0.92 \\
\hline part_agro_av & -15.80 & 0.40 & 11.00 & 0.53 & 10.00 & 0.57 & -0.60 & 0.97 \\
\hline aut & -1.80 & 0.88 & -5.50 & 0.62 & -5.50 & 0.62 & 22.50 & 0.17 \\
\hline bus & -5.60 & 0.66 & -6.80 & 0.50 & -7.60 & 0.45 & 18.40 & 0.25 \\
\hline trucks & -1.90 & 0.89 & -6.00 & 0.60 & -6.30 & 0.59 & 24.00 & 0.12 \\
\hline motorcycles & 1.10 & 0.94 & -20.50 & 0.20 & -20.50 & 0.20 & 24.60 & 0.16 \\
\hline micro-buses & -1.40 & 0.90 & -5.60 & 0.60 & -5.90 & 0.59 & 24.70 & 0.13 \\
\hline urb & 4.60 & 0.74 & 0.10 & 0.99 & 0.70 & 0.96 & 17.40 & 0.22 \\
\hline \multicolumn{9}{|l|}{ Year: 2014} \\
\hline ln_gdp & 13.10 & 0.27 & 5.00 & 0.68 & 6.30 & 0.60 & 13.12 & 0.30 \\
\hline hdi & 1.00 & 0.93 & 3.10 & 0.78 & 3.90 & 0.73 & 0.78 & 0.12 \\
\hline popurban & 9.70 & 0.15 & 1.50 & 0.83 & 4.20 & 0.59 & 45490 & 0.08 \\
\hline c_dae & 6.30 & 0.63 & 5.10 & 0.70 & 2.50 & 0.85 & 0.08 & 1.00 \\
\hline c_ch & 0.00 & 1.00 & -2.20 & 0.87 & -2.50 & 0.84 & 0.15 & 1.00 \\
\hline c_saae & 3.20 & 0.80 & 1.60 & 0.90 & 3.50 & 0.78 & 0.08 & 1.00 \\
\hline c_sae & 0.00 & 1.00 & 1.60 & 0.91 & 1.00 & 0.95 & 0.03 & 1.00 \\
\hline c_sabesp & -3.30 & 0.80 & -2.10 & 0.87 & -0.10 & 0.99 & 0.53 & 0.62 \\
\hline part_ind_av & -0.70 & 0.96 & 6.80 & 0.58 & 5.80 & 0.63 & 20.16 & 0.65 \\
\hline part_agro_av & -4.70 & 0.70 & -1.10 & 0.93 & -0.90 & 0.94 & 13.73 & 0.65 \\
\hline aut & 9.70 & 0.14 & 1.80 & 0.79 & 4.50 & 0.55 & 17071 & 0.04 \\
\hline bus & 10.20 & 0.07 & 0.20 & 0.98 & 2.70 & 0.71 & 162.84 & 0.12 \\
\hline trucks & 11.60 & 0.10 & 3.10 & 0.70 & 5.40 & 0.52 & 1085.40 & 0.05 \\
\hline motorcycles & 10.50 & 0.23 & 0.00 & 1.00 & 2.70 & 0.78 & 6403.30 & 0.02 \\
\hline micro-buses & 10.10 & 0.15 & 2.40 & 0.73 & 5.00 & 0.52 & 3136.20 & 0.03 \\
\hline urb & 4.60 & 0.66 & -1.20 & 0.90 & -0.50 & 0.96 & 89.05 & 0.80 \\
\hline
\end{tabular}

Source: Elaborated by the authors based on the results. 
Table B.8. Balancing statistics between Certificated by GBMP and Non-Certificated by GBMP of 2015 (data without influenza)

\begin{tabular}{|c|c|c|c|c|c|c|c|c|}
\hline \multirow[t]{2}{*}{ Variable } & \multicolumn{2}{|c|}{$\begin{array}{l}\text { Nearest neighbor } \\
\text { without caliper }\end{array}$} & \multicolumn{2}{|c|}{$\begin{array}{l}\text { Nearest neighbor } \\
\text { with caliper }\end{array}$} & \multicolumn{2}{|c|}{ Kernel $^{€}$} & \multicolumn{2}{|c|}{$\begin{array}{l}\text { Matching } \\
\text { covariate }\end{array}$} \\
\hline & Bias (\%) & p-value & Bias (\%) & p-value & Bias (\%) & p-value & Bias (\%) & $\mathrm{p}$-value \\
\hline \multicolumn{9}{|l|}{ Year: 2015} \\
\hline ln_gdp & 7.30 & 0.58 & 1.40 & 0.91 & 3.20 & 0.80 & 15.30 & 0.24 \\
\hline hdi & 2.50 & 0.83 & 2.00 & 0.86 & 3.00 & 0.80 & 22.00 & 0.05 \\
\hline popurban & -2.50 & 0.80 & 0.60 & 0.94 & 1.00 & 0.90 & 23.80 & 0.04 \\
\hline c_dae & -3.90 & 0.78 & 4.70 & 0.70 & 2.80 & 0.82 & 0.00 & 1.00 \\
\hline c_ch & 4.80 & 0.70 & -5.60 & 0.67 & -5.10 & 0.70 & 0.00 & 1.00 \\
\hline c_saae & -6.80 & 0.66 & 4.30 & 0.76 & 4.10 & 0.77 & 0.00 & 1.00 \\
\hline c_sae & 6.60 & 0.56 & 1.40 & 0.92 & 0.60 & 0.96 & 0.00 & 1.00 \\
\hline c_sabesp & 3.60 & 0.79 & 2.80 & 0.83 & 1.90 & 0.89 & -5.00 & 0.70 \\
\hline part_ind_av & 8.60 & 0.49 & 7.50 & 0.55 & 6.00 & 0.64 & 7.00 & 0.55 \\
\hline part_agro_av & 1.50 & 0.90 & 3.10 & 0.81 & 1.40 & 0.91 & -3.10 & 0.79 \\
\hline aut & -2.50 & 0.80 & 1.40 & 0.86 & 1.70 & 0.83 & 27.50 & 0.03 \\
\hline bus & -5.20 & 0.61 & -1.00 & 0.90 & 0.40 & 0.97 & 19.30 & 0.11 \\
\hline trucks & -3.40 & 0.73 & 0.40 & 0.96 & 1.40 & 0.87 & 25.60 & 0.03 \\
\hline motorcycles & 1.70 & 0.86 & -2.30 & 0.82 & 0.10 & 0.99 & 30.40 & 0.02 \\
\hline micro-buses & -2.40 & 0.80 & 1.30 & 0.87 & 2.00 & 0.81 & 29.30 & 0.02 \\
\hline urb & -0.20 & 0.99 & -1.60 & 0.88 & -0.80 & 0.95 & 4.10 & 0.69 \\
\hline
\end{tabular}

Source: Elaborated by the authors based on the results. 
Table B.9. Balancing statistics between Certificated by GBMP and Non-Certificated by GBMP from 2009 to 2010 (data with assaults)

\begin{tabular}{|c|c|c|c|c|c|c|c|c|}
\hline \multirow[t]{2}{*}{ Variable } & \multicolumn{2}{|c|}{$\begin{array}{l}\text { Nearest neighbor } \\
\text { without caliper }\end{array}$} & \multicolumn{2}{|c|}{$\begin{array}{l}\text { Nearest neighbor } \\
\text { with caliper }^{\dagger}\end{array}$} & \multicolumn{2}{|c|}{ Kernel $^{€}$} & \multicolumn{2}{|c|}{$\begin{array}{l}\text { Matching } \\
\text { covariate }\end{array}$} \\
\hline & Bias (\%) & p-value & Bias (\%) & p-value & Bias (\%) & p-value & Bias (\%) & $\mathrm{p}$-value \\
\hline \multicolumn{9}{|l|}{ Year: 2009} \\
\hline ln_gdp & 0.80 & 0.94 & 2.70 & 0.79 & 2.40 & 0.81 & 10.00 & 0.34 \\
\hline hdi & 0.50 & 0.96 & 2.50 & 0.80 & 3.30 & 0.74 & 16.20 & 0.09 \\
\hline popurban & -2.90 & 0.78 & 1.00 & 0.92 & 0.70 & 0.94 & 5.10 & 0.62 \\
\hline c_dae & 2.30 & 0.80 & -0.50 & 0.96 & -1.30 & 0.9 & 4.50 & 0.65 \\
\hline c_ch & 0.00 & 1.00 & -2.40 & 0.83 & -3.60 & 0.74 & 0.00 & 1.00 \\
\hline c_saae & 0.00 & 1.00 & -0.60 & 0.95 & -0.90 & 0.93 & 0.00 & 1.00 \\
\hline c_sae & -3.50 & 0.79 & 0.50 & 0.97 & 0.60 & 0.96 & 0.00 & 1.00 \\
\hline c_sabesp & 5.00 & 0.65 & 2.70 & 0.80 & 4.20 & 0.7 & -3.60 & 0.74 \\
\hline part_ind_av & 6.80 & 0.49 & 1.10 & 0.91 & 0.00 & 1 & 2.60 & 0.80 \\
\hline part_agro_av & -0.40 & 0.97 & -3.00 & 0.79 & -1.40 & 0.9 & -3.20 & 0.77 \\
\hline aut & -3.00 & 0.74 & 0.70 & 0.94 & 0.50 & 0.95 & 19.50 & 0.02 \\
\hline bus & -3.10 & 0.72 & 0.20 & 0.98 & 0.00 & 1 & 16.90 & 0.03 \\
\hline trucks & -4.00 & 0.65 & 0.60 & 0.95 & 0.40 & 0.96 & 18.60 & 0.03 \\
\hline motorcycles & -1.80 & 0.84 & 2.30 & 0.79 & 2.30 & 0.78 & 19.90 & 0.05 \\
\hline micro-buses & -3.30 & 0.70 & 1.00 & 0.91 & 0.80 & 0.92 & 20.40 & 0.03 \\
\hline urb & -2.50 & 0.79 & 0.70 & 0.94 & 1.00 & 0.92 & 1.50 & 0.87 \\
\hline \multicolumn{9}{|l|}{ Year: 2010} \\
\hline ln_gdp & 5.00 & 0.62 & -0.50 & 0.96 & 0.80 & 0.94 & 11.20 & 0.32 \\
\hline hdi & 4.90 & 0.65 & -1.30 & 0.91 & -0.50 & 0.96 & 11.70 & 0.27 \\
\hline popurban & 0.50 & 0.66 & -0.30 & 0.79 & -0.10 & 0.91 & 13.70 & 0.24 \\
\hline c_dae & 0.00 & 1.00 & -2.10 & 0.86 & -3.00 & 0.80 & -2.60 & 0.81 \\
\hline c_ch & -5.70 & 0.63 & -2.40 & 0.84 & -3.30 & 0.78 & 0.00 & 1.00 \\
\hline c_saae & 2.90 & 0.80 & 1.30 & 0.91 & 0.00 & 1.00 & 0.00 & 1.00 \\
\hline c_sae & 3.70 & 0.79 & 2.80 & 0.84 & 3.50 & 0.81 & 0.00 & 1.00 \\
\hline c_sabesp & -1.50 & 0.90 & 5.80 & 0.63 & 4.80 & 0.69 & 0.00 & 1.00 \\
\hline part_ind_av & 4.60 & 0.67 & 2.00 & 0.86 & 0.50 & 0.97 & -2.40 & 0.82 \\
\hline part_agro_av & -1.50 & 0.90 & 0.60 & 0.96 & 0.00 & 1.00 & 0.60 & 0.96 \\
\hline aut & 0.50 & 0.59 & -0.30 & 0.81 & -0.10 & 0.91 & 13.90 & 0.24 \\
\hline bus & 0.50 & 0.53 & -0.50 & 0.64 & -0.30 & 0.80 & 13.00 & 0.27 \\
\hline trucks & 1.10 & 0.48 & -0.30 & 0.87 & 0.00 & 1.00 & 14.80 & 0.21 \\
\hline motorcycles & 0.90 & 0.66 & -1.50 & 0.55 & -0.50 & 0.82 & 15.80 & 0.18 \\
\hline micro-buses & 0.40 & 0.63 & -0.30 & 0.77 & -0.10 & 0.91 & 13.90 & 0.24 \\
\hline urb & -4.00 & 0.67 & -0.60 & 0.96 & 0.10 & 0.99 & -1.60 & 0.87 \\
\hline
\end{tabular}

Source: Elaborated by the authors based on the results. 
Table B.10. Balancing statistics between Certificated by GBMP and Non-Certificated by GBMP from 2011 to 2012 (data with assaults)

\begin{tabular}{|c|c|c|c|c|c|c|c|c|}
\hline \multirow[t]{2}{*}{ Variable } & \multicolumn{2}{|c|}{$\begin{array}{l}\text { Nearest neighbor } \\
\text { without caliper }\end{array}$} & \multicolumn{2}{|c|}{$\begin{array}{l}\text { Nearest neighbor } \\
\text { with caliper }^{\dagger}\end{array}$} & \multicolumn{2}{|c|}{ Kernel $^{€}$} & \multicolumn{2}{|c|}{$\begin{array}{l}\text { Matching } \\
\text { covariate }\end{array}$} \\
\hline & Bias (\%) & p-value & Bias (\%) & p-value & Bias (\%) & p-value & Bias (\%) & $\mathrm{p}$-value \\
\hline \multicolumn{9}{|l|}{ Year: 2011} \\
\hline ln_gdp & 10.60 & 0.29 & 8.90 & 0.38 & 7.40 & 0.47 & 17.30 & 0.10 \\
\hline hdi & 0.60 & 0.96 & 7.10 & 0.51 & 6.50 & 0.55 & 16.00 & 0.14 \\
\hline popurban & 0.40 & 0.76 & 0.70 & 0.56 & 0.50 & 0.70 & 13.70 & 0.21 \\
\hline c_dae & -9.80 & 0.40 & -0.30 & 0.98 & -1.60 & 0.88 & 0.00 & 1.00 \\
\hline c_ch & 0.00 & 1.00 & -0.20 & 0.99 & -0.60 & 0.96 & 0.00 & 1.00 \\
\hline c_saae & 0.00 & 1.00 & 0.70 & 0.95 & -0.80 & 0.94 & 0.00 & 1.00 \\
\hline c_sae & 6.20 & 0.63 & 0.70 & 0.96 & 2.20 & 0.87 & 0.00 & 1.00 \\
\hline c_sabesp & 2.60 & 0.82 & 0.60 & 0.96 & 1.50 & 0.89 & -1.20 & 0.91 \\
\hline part_ind_av & 5.10 & 0.62 & 6.00 & 0.57 & 4.10 & 0.69 & 2.20 & 0.82 \\
\hline part_agro_av & -9.20 & 0.44 & -8.60 & 0.47 & -6.10 & 0.61 & -0.60 & 0.95 \\
\hline aut & 0.30 & 0.84 & 0.60 & 0.61 & 0.40 & 0.74 & 14.00 & 0.20 \\
\hline bus & 0.30 & 0.84 & 0.50 & 0.70 & 0.20 & 0.85 & 13.00 & 0.24 \\
\hline trucks & 0.60 & 0.78 & 1.20 & 0.58 & 0.80 & 0.69 & 15.60 & 0.15 \\
\hline motorcycles & 1.30 & 0.57 & 1.60 & 0.50 & 1.20 & 0.62 & 16.30 & 0.14 \\
\hline micro-buses & 0.30 & 0.78 & 0.60 & 0.58 & 0.40 & 0.71 & 14.10 & 0.20 \\
\hline urb & 3.70 & 0.70 & 4.00 & 0.68 & 3.50 & 0.72 & 2.40 & 0.79 \\
\hline \multicolumn{9}{|l|}{ Year: 2012} \\
\hline ln_gdp & 6.00 & 0.60 & -5.60 & 0.64 & -1.90 & 0.88 & 9.60 & 0.41 \\
\hline hdi & 8.00 & 0.51 & -2.80 & 0.82 & 0.20 & 0.99 & 7.80 & 0.50 \\
\hline popurban & 1.70 & 0.21 & -0.10 & 0.93 & 0.40 & 0.80 & 13.80 & 0.24 \\
\hline c_dae & 5.80 & 0.61 & 2.90 & 0.81 & 3.30 & 0.78 & -2.80 & 0.81 \\
\hline c_ch & 9.90 & 0.37 & -0.80 & 0.94 & -1.50 & 0.90 & 0.00 & 1.00 \\
\hline c_saae & 6.10 & 0.59 & 2.30 & 0.85 & 2.40 & 0.84 & 0.00 & 1.00 \\
\hline c_sae & 0.00 & 1.00 & -2.80 & 0.85 & -2.50 & 0.87 & 0.00 & 1.00 \\
\hline c_sabesp & -19.00 & 0.11 & -4.80 & 0.70 & -7.50 & 0.53 & 1.40 & 0.91 \\
\hline part_ind_av & 3.70 & 0.74 & 1.90 & 0.86 & 4.40 & 0.69 & -4.90 & 0.65 \\
\hline part_agro_av & -11.60 & 0.36 & -1.30 & 0.92 & -2.30 & 0.85 & -1.60 & 0.89 \\
\hline aut & 1.80 & 0.15 & 0.30 & 0.79 & 0.80 & 0.53 & 16.00 & 0.18 \\
\hline bus & 1.10 & 0.32 & -1.10 & 0.40 & -0.70 & 0.63 & 13.90 & 0.24 \\
\hline trucks & 3.10 & 0.18 & -1.10 & 0.66 & -0.20 & 0.95 & 18.30 & 0.12 \\
\hline motorcycles & 3.00 & 0.25 & 2.00 & 0.42 & 2.40 & 0.34 & 18.40 & 0.12 \\
\hline micro-buses & 1.90 & 0.14 & -0.20 & 0.91 & 0.40 & 0.79 & 16.30 & 0.17 \\
\hline urb & -4.10 & 0.68 & -2.70 & 0.80 & -2.00 & 0.85 & 1.00 & 0.92 \\
\hline
\end{tabular}

Source: Elaborated by the authors based on the results. 
Table B.11. Balancing statistics between Certificated by GBMP and Non-Certificated by GBMP from 2013 to 2014 (data with assaults)

\begin{tabular}{|c|c|c|c|c|c|c|c|c|}
\hline \multirow[t]{2}{*}{ Variable } & \multicolumn{2}{|c|}{$\begin{array}{l}\text { Nearest neighbor } \\
\text { without caliper }\end{array}$} & \multicolumn{2}{|c|}{$\begin{array}{l}\text { Nearest neighbor } \\
\text { with caliper }^{\dagger}\end{array}$} & \multicolumn{2}{|c|}{ Kernel $^{€}$} & \multicolumn{2}{|c|}{$\begin{array}{l}\text { Matching } \\
\text { covariate }\end{array}$} \\
\hline & Bias (\%) & p-value & Bias (\%) & p-value & Bias (\%) & p-value & Bias (\%) & $\mathrm{p}$-value \\
\hline \multicolumn{9}{|l|}{ Year: 2013} \\
\hline ln_gdp & 8.70 & 0.61 & -8.90 & 0.60 & -8.50 & 0.61 & 16.40 & 0.34 \\
\hline hdi & 9.60 & 0.54 & 3.20 & 0.83 & 3.20 & 0.84 & 20.50 & 0.16 \\
\hline popurban & -1.70 & 0.89 & -6.90 & 0.55 & -7.00 & 0.55 & 18.70 & 0.24 \\
\hline c_dae & -5.30 & 0.77 & -2.30 & 0.89 & 0.50 & 0.98 & 0.00 & 1.00 \\
\hline c_ch & 3.90 & 0.81 & 2.40 & 0.88 & 2.70 & 0.86 & 0.00 & 1.00 \\
\hline c_saae & 0.00 & 1.00 & 12.00 & 0.49 & 12.30 & 0.47 & 0.00 & 1.00 \\
\hline c_sae & -8.00 & 0.70 & 4.10 & 0.83 & 3.60 & 0.85 & 0.00 & 1.00 \\
\hline c_sabesp & -2.80 & 0.87 & 8.30 & 0.63 & 8.10 & 0.63 & 0.00 & 1.00 \\
\hline part_ind_av & 15.50 & 0.35 & -4.30 & 0.79 & -1.40 & 0.93 & 1.60 & 0.92 \\
\hline part_agro_av & -15.80 & 0.40 & 11.00 & 0.53 & 10.00 & 0.57 & -0.60 & 0.97 \\
\hline aut & -1.80 & 0.88 & -5.50 & 0.62 & -5.50 & 0.62 & 22.50 & 0.17 \\
\hline bus & -5.60 & 0.66 & -6.80 & 0.50 & -7.60 & 0.45 & 18.40 & 0.25 \\
\hline trucks & -1.90 & 0.89 & -6.00 & 0.60 & -6.30 & 0.59 & 24.00 & 0.12 \\
\hline motorcycles & 1.10 & 0.94 & -20.50 & 0.20 & -20.50 & 0.20 & 24.60 & 0.16 \\
\hline micro-buses & -1.40 & 0.90 & -5.60 & 0.60 & -5.90 & 0.59 & 24.70 & 0.13 \\
\hline urb & 4.60 & 0.74 & 0.10 & 0.99 & 0.70 & 0.96 & 17.40 & 0.22 \\
\hline \multicolumn{9}{|l|}{ Year: 2014} \\
\hline ln_gdp & 13.10 & 0.27 & 5.00 & 0.68 & 6.30 & 0.60 & 13.10 & 0.30 \\
\hline hdi & 1.00 & 0.93 & 3.10 & 0.78 & 3.90 & 0.73 & 17.50 & 0.12 \\
\hline popurban & 9.70 & 0.15 & 1.50 & 0.83 & 4.20 & 0.59 & 20.30 & 0.08 \\
\hline c_dae & 6.30 & 0.63 & 5.10 & 0.70 & 2.50 & 0.85 & 0.00 & 1.00 \\
\hline c_ch & 0.00 & 1.00 & -2.20 & 0.87 & -2.50 & 0.84 & 0.00 & 1.00 \\
\hline c_saae & 3.20 & 0.80 & 1.60 & 0.90 & 3.50 & 0.78 & 0.00 & 1.00 \\
\hline c_sae & 0.00 & 1.00 & 1.60 & 0.91 & 1.00 & 0.95 & 0.00 & 1.00 \\
\hline c_sabesp & -3.30 & 0.80 & -2.10 & 0.87 & -0.10 & 0.99 & -6.20 & 0.62 \\
\hline part_ind_av & -0.70 & 0.96 & 6.80 & 0.58 & 5.80 & 0.63 & 5.20 & 0.65 \\
\hline part_agro_av & -4.70 & 0.70 & -1.10 & 0.93 & -0.90 & 0.94 & -5.10 & 0.65 \\
\hline aut & 9.70 & 0.14 & 1.80 & 0.79 & 4.50 & 0.55 & 24.70 & 0.04 \\
\hline bus & 10.20 & 0.07 & 0.20 & 0.98 & 2.70 & 0.71 & 17.80 & 0.12 \\
\hline trucks & 11.60 & 0.10 & 3.10 & 0.70 & 5.40 & 0.52 & 22.80 & 0.05 \\
\hline motorcycles & 10.50 & 0.23 & 0.00 & 1.00 & 2.70 & 0.78 & 29.10 & 0.02 \\
\hline micro-buses & 10.10 & 0.15 & 2.40 & 0.73 & 5.00 & 0.52 & 26.90 & 0.03 \\
\hline urb & 4.60 & 0.66 & -1.20 & 0.90 & -0.50 & 0.96 & 2.50 & 0.80 \\
\hline
\end{tabular}

Source: Elaborated by the authors based on the results. 
Table B.12. Balancing statistics between Certificated by GBMP and Non-Certificated by GBMP of 2015 (data with assaults)

\begin{tabular}{|c|c|c|c|c|c|c|c|c|}
\hline \multirow[t]{2}{*}{ Variable } & \multicolumn{2}{|c|}{$\begin{array}{l}\text { Nearest neighbor } \\
\text { without caliper }\end{array}$} & \multicolumn{2}{|c|}{$\begin{array}{l}\text { Nearest neighbor } \\
\text { with caliper }\end{array}$} & \multicolumn{2}{|c|}{ Kernel $^{€}$} & \multicolumn{2}{|c|}{$\begin{array}{l}\text { Matching } \\
\text { covariate }\end{array}$} \\
\hline & Bias (\%) & p-value & Bias (\%) & p-value & Bias (\%) & p-value & Bias (\%) & $\mathrm{p}$-value \\
\hline \multicolumn{9}{|l|}{ Year: 2015} \\
\hline ln_gdp & 7.30 & 0.58 & 1.40 & 0.91 & 3.20 & 0.80 & 15.30 & 0.24 \\
\hline hdi & 2.50 & 0.83 & 2.00 & 0.86 & 3.00 & 0.80 & 22.00 & 0.05 \\
\hline popurban & -2.50 & 0.80 & 0.60 & 0.94 & 1.00 & 0.90 & 23.80 & 0.04 \\
\hline c_dae & -3.90 & 0.78 & 4.70 & 0.70 & 2.80 & 0.82 & 0.00 & 1.00 \\
\hline c_ch & 4.80 & 0.70 & -5.60 & 0.67 & -5.10 & 0.70 & 0.00 & 1.00 \\
\hline c_saae & -6.80 & 0.66 & 4.30 & 0.76 & 4.10 & 0.77 & 0.00 & 1.00 \\
\hline c_sae & 6.60 & 0.56 & 1.40 & 0.92 & 0.60 & 0.96 & 0.00 & 1.00 \\
\hline c_sabesp & 3.60 & 0.79 & 2.80 & 0.83 & 1.90 & 0.89 & -5.00 & 0.70 \\
\hline part_ind_av & 8.60 & 0.49 & 7.50 & 0.55 & 6.00 & 0.64 & 7.00 & 0.55 \\
\hline part_agro_av & 1.50 & 0.90 & 3.10 & 0.81 & 1.40 & 0.91 & -3.10 & 0.79 \\
\hline aut & -2.50 & 0.80 & 1.40 & 0.86 & 1.70 & 0.83 & 27.50 & 0.03 \\
\hline bus & -5.20 & 0.61 & -1.00 & 0.90 & 0.40 & 0.97 & 19.30 & 0.11 \\
\hline trucks & -3.40 & 0.73 & 0.40 & 0.96 & 1.40 & 0.87 & 25.60 & 0.03 \\
\hline motorcycles & 1.70 & 0.86 & -2.30 & 0.82 & 0.10 & 0.99 & 30.40 & 0.02 \\
\hline micro-buses & -2.40 & 0.80 & 1.30 & 0.87 & 2.00 & 0.81 & 29.30 & 0.02 \\
\hline urb & -0.20 & 0.99 & -1.60 & 0.88 & -0.80 & 0.95 & 4.10 & 0.69 \\
\hline
\end{tabular}

Source: Elaborated by the authors based on the results. 